Discussion Paper No. 11-022

Geographical and Institutional Distances in Venture Capital Deals: How Syndication and Experience Drive Internationalization Patterns

Tereza Tykvová and Andrea Schertler

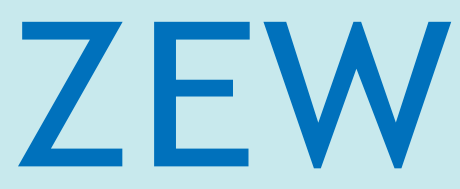

Zentrum für Europäische Wirtschaftsforschung $\mathrm{GmbH}$

Centre for European

Economic Research 
Discussion Paper No. 11-022

\title{
Geographical and Institutional Distances in Venture Capital Deals: How Syndication and Experience Drive Internationalization Patterns
}

\author{
Tereza Tykvová and Andrea Schertler
}

Download this ZEW Discussion Paper from our ftp server:

ftp://ftp.zew.de/pub/zew-docs/dp/dp11022.pdf

Die Discussion Papers dienen einer möglichst schnellen Verbreitung von neueren Forschungsarbeiten des ZEW. Die Beiträge liegen in alleiniger Verantwortung der Autoren und stellen nicht notwendigerweise die Meinung des ZEW dar.

Discussion Papers are intended to make results of ZEW research promptly available to other economists in order to encourage discussion and suggestions for revisions. The authors are solely responsible for the contents which do not necessarily represent the opinion of the ZEW. 


\section{Non-Technical Summary}

In the last decade, more than one third of worldwide venture capital investments have been crossborder deals. In many of these deals venture capitalists cross continents and/or invest in countries with different legal systems and cultural institutions. Drawing on a novel dataset of worldwide venture capital deals, we investigate how venture capitalists overcome the complexity of investing in geographically and institutionally distant regions. Our results suggest that syndication with local venture capitalists reduces foreign venture capitalists' obstacles arising from lacking geographical and institutional proximity to the portfolio company as well as offsets their lacking general and withincountry experience. In addition, our findings indicate that repeated relationships between foreign and local venture capitalists are able to reduce potential frictions which may arise between syndication partners over short as well as over long geographical distances.

We find that internationalization is not only an issue for a handful of large experienced global venture capitalists jetting across continents. It is not the case that smaller, less experienced venture capitalists are not able to exploit the potential advantages stemming from internationalization. Our results indicate that experienced local venture capitalists invite experienced foreign partners, while inexperienced local venture capitalists invite less experienced foreign ones. Consequently, syndication with an inexperienced local venture capitalist may be a successful way for inexperienced foreign venture capitalists to overcome the obstacles of geographical and institutional distances. This result of our analysis is of particular relevance for venture capitalists with small experience who want to expand their activities beyond their countries' borders but who do not (yet) have direct access to deals in foreign countries. These investors may start their international expansion via syndication with inexperienced local venture capitalists in small deals. In the course of time, as they become more and more experienced and possess better contacts to other venture capitalists through repeated interactions, they may not only gain access to cross-border deals on their own but they may also be able to invest in larger deals and to join cross-border syndicates led by more experienced venture capitalists. 


\section{Das Wichtigste in Kürze}

Bei einem Drittel aller weltweit stattfindenden Venture-Capital-Investitionen handelte es sich um grenzüberschreitende Transaktionen. Ein beträchtlicher Anteil dieser Transaktionen wurde sogar über lange geographische und institutionelle Entfernungen ausgeführt. Diese Studie geht der Frage nach, welche VC-Investoren über lange geographische und institutionelle Entfernungen investieren. Dabei haben VC-Investoren zwei primäre Wege grenzüberschreitend zu investieren: Sie investieren entweder alleine in ein Portfoliounternehmen (Standalone-Investition) oder sie werden von einem lokalen VCInvestor eingeladen, an einer Transaktion teilzunehmen. Unsere Ergebnisse zeigen, dass die geographische und institutionelle Entfernung des ausländischen Investors zum Portfoliounternehmen die Wahrscheinlichkeit seiner Teilnahme reduziert. Der negative Effekt ist für StandaloneInvestitionen wesentlich stärker ausgeprägt, als für Investitionen zu denen der ausländische Investor von einem lokalen Investor eingeladen wird. Darüber hinaus erfordert eine solche, über Ländergrenzen hinweg stattfindende, Syndizierung weniger allgemeine und länderspezifische Erfahrung des ausländischen Investors als Standalone-Investitionen. Wiederholte Kooperation zwischen den Investoren scheint potentielle Konflikte zwischen den Syndikatspartnern nicht nur über kurze, sondern auch über lange Distanzen zu reduzieren.

Internationalisierung beschränkt sich nicht nur auf eine Handvoll großer, erfahrener und weltweit agierender VC-Investoren. Auch kleinere, weniger erfahrene VC-Investoren können von den mit einer Internationalisierung verbundenen Vorteilen profitieren. Unsere Ergebnisse zeigen, dass erfahrene lokale VC-Investoren primär erfahrene ausländische Partner ansprechen. Jedoch syndizieren weniger erfahrene lokale VC-Investoren auch mit weniger erfahrenen ausländischen VC-Investoren. Eine grenzübergreifende Syndizierung unter kleinen VC-Investoren kann ein erfolgversprechender Weg sein, geographische und institutionelle Distanzen zu überbrücken. Dieses Ergebnis unserer Studie ist für unerfahrene VC-Investoren, die ihre Aktivitäten ins Ausland ausweiten möchten, von besonderem Interesse. Für diese Investoren liegt es nahe, ihre internationale Expansion mit Hilfe einer Syndizierung mit ausländischen VC-Investoren mit ähnlicher Erfahrung durchzuführen. Im Laufe der Zeit - mit wachsender Erfahrung und einer Ausweitung eigener Netzwerke - kann der zunächst unerfahrene VC-Investor einen eigenständigen Zugang zu Transaktionen im Ausland erreichen und ebenfalls in die Lage kommen, mit erfahrenen Partnern vor Ort zu kooperieren. 


\title{
Geographical and Institutional Distances in Venture Capital Deals: How Syndication and Experience Drive Internationalization Patterns
}

\author{
Tereza Tykvová (ZEW Mannheim) \\ Andrea Schertler (University of Groningen)
}

EFA 2010 Frankfurt Meetings Paper

\begin{abstract}
:
Drawing on a novel dataset of worldwide venture capital deals, we investigate how venture capitalists (VCs) overcome the complexity of investing in geographically and institutionally distant regions. Our results indicate that syndicating with local VCs is a common way for foreign VCs to gain deal access, overcome the complexity of investing in distant regions and offset their lack of within-country experience. The foreign VC's distance from the portfolio company ceases to be a serious investment obstacle when he can rely on a highly experienced local VC. Our results further suggest that inexperienced VCs, i.e. those VCs with a large need for syndication, increase their chances to invest across borders when they invest in small deals jointly with local inexperienced partners.
\end{abstract}

Keywords: Multiple Regression Analysis, Syndicates, Venture Capital, Internationalization, Distance, Experience

JEL Classification: F21, G24.

Acknowledgements: Financial support from the EU 7th Research Framework Programme is gratefully acknowledged (Project title: Financing Entrepreneurial Ventures in Europe: Impact on Innovation, Employment Growth, and Competitiveness, Grant Agreement Number 217485). The authors are indebted to the Bureau van Dijk Electronic Publishing (BvDEP) for providing the data. The current version has benefited from comments by Vladimir Atanasov, Douglas Cumming, Reint Gropp, Niels Hermes, Christian Hopp, Jan Pieter Krahnen, Ernst Maug, Elisabeth Müller, Alexandra Niessen, Øyvind Norli, Charlotte Ostegaard, Per Østberg, Richard Smith, Eric Theissen, George M. von Furstenberg, Uwe Walz, participants at the Conference of the ECB-CFS Research Network, the EFA Conference, the FMA European Conference, the BI Norwegian School of Management Conference, the SGF Conference, the DGF Conference, the conference of the Verein für Socialpolitik, the SUERF Conference and the CFR Research Seminar. Jonas Vogt provided excellent research assistance. 


\section{INTRODUCTION}

In the last decade, more than one third of worldwide venture capital investments have been crossborder deals. In many of these deals venture capitalists (VCs) cross continents and/or invest in countries with different legal systems and cultural institutions. This is astonishing at first sight given the information and agency problems inherent in venture capital transactions. Even more surprising is that many of these deals are not carried out by large global players, but by small and less experienced VCs. The existing research has not systematically examined how VCs (and in particular less experienced VCs) overcome the complexity of investing in geographically and institutionally distant regions. We fill this gap in the literature by applying a novel approach in a comprehensive dataset of worldwide deals. We take into account that VCs typically either invest alone in foreign portfolio companies (PCs) or they syndicate with VCs located in the PC country. Unfortunately, these two types of cross-border deals are not directly comparable because in the first case VCs directly access PCs in foreign countries whereas in the second case a local VC invites PCs to participate and form a joint syndicate. Therefore, we first investigate foreign VCs' participation likelihoods in syndicated and stand-alone cross-border deals and then investigate the participation likelihoods of foreign and nonlead local VCs in syndicated deals.

To model foreign VCs' participation likelihoods in cross-border deals, we generate all possible combinations of each of these deals with all the VCs located outside the country where the deal takes place. This approach captures the foreign VC's perspective and allows us to address the following three research questions in a single framework. First, does syndication with a local VC mitigate the negative effects of the geographical and institutional distances? Information and agency problems between the foreign VC and the PC increase as the geographical and institutional distances between the VC and the PC increase. We expect that these problems are mitigated when a distant VC syndicates with a VC who is located geographically close to the PC and has the same institutional background. Second, does syndication with a local VC help offset the foreign VC's lack of general experience as well as experience in the country where the deal takes place? It is difficult for VCs who lack general and within-country experience to directly access investment opportunities in a foreign country, to evaluate investment opportunities and, later on, to monitor and support their PCs. Therefore, we expect that inexperienced VCs more often rely on a local syndication partner than experienced VCs. Third, does mutual trust between the VCs stemming from repeated relationships reach across borders and over long geographical distances? The existence of repeated relationships reduces informational frictions between the contracting parties in a syndicate. Therefore, we expect that they increase the foreign VC's participation likelihood. However, repeated relationships might lose effectiveness over long geographical distances.

To model VCs' participation likelihoods in syndicated deals, we generate all the possible combinations of each of these deals with all VCs from the sample except the local VC who leads the syndicate. This approach captures the local VC's perspective and allows us to examine how the local 
VC chooses his (foreign or local) syndication partner. With this approach, we address the following two research questions. First, does the local VC's experience mitigate the negative effects of the partner's geographical and institutional distances? Experienced local VCs manage information and agency problems arising from long distances between syndication partners better than inexperienced local VCs. In addition, as the experience of the local VC increases, the distant VC is more willing to rely on the local VC's expertise in screening, monitoring and supporting the PC, which renders his own distance less important. Therefore we expect that the local VC's experience moderates the negative effects of distances on participation likelihoods. Second, how does the local VC's experience affect the selection of a foreign syndication partner in terms of the partner's general and withincountry experience? We expect that an experienced local VC does not invite inexperienced foreign partners since the benefits these VCs can contribute are small. However, an inexperienced local VC might invite inexperienced foreign partners and by doing so offer them a chance to internationalize.

The findings of our study increase our understanding of internationalization within venture capital industries. Our most innovative and important contributions to the literature come from our model of VCs' participation likelihoods in syndicated deals. To the best of our knowledge, our study is the first that considers syndication behavior in worldwide venture capital deals. We demonstrate that syndication partners' participation likelihoods decrease in their geographical distances from the PC only when an inexperienced local VC leads the syndicate, but not when an experienced local VC is the lead. Thus, the local VC's experience moderates the discouraging impact of the geographical distance on participation likelihoods. Moreover, we document that foreign VCs who lack general and withincountry experience have the chance to join a local VC only if this local VC also is inexperienced, while experienced local VCs require large experience from their syndication partners. This finding is consistent with the recent theoretical literature on syndication behavior, which suggests that more experienced VCs choose more experienced syndication partners (Casamatta and Haritchabalet 2007, Cestone et al. 2007).

The results from our model of foreign VCs' participation likelihoods in cross-border deals contribute to the emerging literature on internationalization in these industries. The recent literature shows that geographical and institutional distances negatively affect the intensity of bilateral venture capital flows between countries (e.g., Aizenman and Kendall 2008). We add to this finding by showing that the negative effects of geographical and institutional distances are more pronounced for stand-alone crossborder deals than for deals syndicated with a local VC. Our results from the aggregate level ananlysis demonstrate that the bilateral volumes of stand-alone deals are more strongly affected by geographical and institutional distances between the VC and PC country than the bilateral volumes of deals syndicated with local VCs. Another strand of the literature points out that VCs' experience plays a decisive role in cross-border investments. Recent evidence suggests that U.S. VCs with more international experience (Guler and Guillén 2010a) and European private equity investors with more international human capital (Prijcker et al. 2009) expand faster and more often into foreign countries. We complement these findings by showing that syndication with a local VC might- to a certain extent—offset the lack of the foreign VC's general and within-country experience. Foreign VCs need 
much more experience when they invest alone than they need to be invited by a local VC to participate in a joint deal. Our results suggest that even a VC who has no experience in a particular country has a much better chance to invest in that country when he teams up with local VCs than when he invests alone.

The recent literature also examines the ways investors participate in cross-border deals. Meuleman and Wright (2011) investigate the characteristics U.K. private equity investors have when investing alone in Continental Europe versus when syndicating with a local investor. They find that more experienced U.K. investors prefer stand-alone deals to syndicated deals. This finding is confirmed in our analysis from the foreign VC's perspective, although we determine the participation likelihoods in cross-border deals, while they determine the likelihood to carry out a stand-alone deal instead of a syndicated deal. Our model of foreign VCs' participation likelihoods, which considers all VCs as potential participating VCs irrespective of their location and experience, allows us to extend Meuleman and Wright's findings not only with respect to geographical and institutional distances but also with respect to repeated relationships. The recent theoretical literature suggests that repeated relationships contribute to the reduction of informational frictions between the contracting parties in a syndicate (Chemmanur and Tian 2009, Tykvová 2007) and recent empirical work from U.K. private equity investors is in line with this reasoning (Meuleman et al. 2009). However, it is so far an open empirical question whether repeated relationships work over long distances. Our paper is the first to show that repeated relationships work effectively over long geographical distances.

We draw on a comprehensive dataset that covers VCs from 48 countries, whereas most other studies at the micro level focus on VCs from one country only (e.g., Guler and Guillén 2010a, 2010b, Iriyama and Madhavan 2009, Meuleman and Wright 2011). The scope of our dataset allows us to examine worldwide venture capital cross-border activities and to investigate how foreign VCs' general and within-country experience, geographical and institutional distances as well as repeated relationships affect their participation in cross-border deals. It also allows us to investigate how VCs choose their syndication partners and derive participation likelihoods of VCs located worldwide since we consider all (local and foreign) VCs who participate in a syndicate. While our research questions concerning the VCs' participation likelihoods in cross-border deals could be investigated in a dataset consisting of VCs from one country only, our research questions concerning VCs' participation likelihoods in syndicated deals can only be answered if we include VCs located worldwide.

\section{BACKGROUND AND HYPOTHESES DEVELOPMENT}

Our hypotheses development begins with the observation that VCs typically invest across borders either by carrying out a stand-alone deal or by teaming up with a local VC who usually has the initial deal access, leads the syndicate, and is located geographically close to the PC. We first develop hypotheses related to the likelihood of a foreign VC participating in a cross-border deal either by 
investing alone or by investing alongside a local VC. Second, we develop hypotheses related to the likelihood of a local VC inviting a foreign VC to participate in the deal.

\section{Participation in Cross-border Deals}

VCs may strive for investing across borders to exploit profitable and innovative investment opportunities and/or to diversify their portfolios across countries. While no evidence exists that VCs' cross-border deals offer higher expected returns than their local deals, findings from recent empirical studies suggest that return differences spur cross-border deals. These studies document that worldwide venture capital flows between the VC and PC countries respond positively to the expected growth in the PC country and negatively to that in the VC country (Schertler and Tykvová 2011). Moreover, countries with developed national systems of innovation, which generate more promising investment opportunities, attract larger cross-border venture capital flows than countries with less developed national systems of innovation. More specifically, U.S. VCs invest into countries with a higher patenting activity (Guler and Guillén 2010a, 2010b), and VCs located worldwide target countries with more university students (Aizenman and Kendall 2008) and higher business R\&D expenditures (Schertler and Tykvová 2011). Finally, countries with more viable financial markets, which promise better exit possibilities and therefore better return opportunities (Black and Gilson 1998), attract larger cross-border venture capital inflows than countries with poor financial markets (Guler and Guillén 2010a, 2010b, Aizenman and Kendall 2008, Schertler and Tykvová 2011). These findings indicate that VCs cross borders when they expect higher returns abroad than at home.

However, when VCs invest across borders and over long geographical distances, they miss potential gains proceeding from geographical proximity to their PCs. VCs are believed to gain from geographical proximity to their PCs (e.g., Wright et al. 2005, Cumming and Johan 2006, Lerner 1995, Sorenson and Stuart 2001) since closely located VCs are familiar with local practices, have regional business experience and access to soft information through their managers' interactions in social, civic and business meetings and their participation in formal as well as in informal networks. These factors will affect their relationships to the PCs through all investment stages in which the nature of the information gives rise to information and agency costs as well as to transaction costs of negotiation and renegotiation (e.g., Ueda 2004, Kaplan and Strömberg 2003). An extensive literature concerning different types of investments lends strong support to the argument that investors close to the investment opportunity have lower information costs than more distant investors (e.g., Kang and Kim 2008, 2010, Coval and Moskowitz 1999, Ivkovic and Weisbenner 2005, Agarwal and Hauswald 2010 among others). Also the empirical literature on venture capital finance suggests that it is less costly to find (Wright et al. 2005), to screen (Cumming and Johan 2006) as well as to monitor and support (Lerner 1995, Sorenson and Stuart 2001) geographically close PCs than distant ones. Consequently, VCs tend to invest in closely located PCs (Sorenson and Stuart 2001, Florida and Kenney 1988, Powell et al. 2002) and if they cross borders they prefer geographically close countries to distant ones (Aizenman and Kendall 2008). 
In addition to geographical distance, institutional distance, i.e., differences in legal systems, language, habits, and attitudes (Boschma 2005), may also hinder cross-border venture capital deals. A country's legal system shapes the contract design (e.g., Bottazzi et al. 2009, Schoar and Lerner 2004) that VCs use to incentivize the PCs' managers to perform well (Kaplan and Strömberg 2003, 2004). Empirical studies confirm that contract design plays a decisive role for the PCs' success (e.g., Cumming et al. 2006, Hege et al. 2009). Empirical evidence from cross-border venture capital flows suggests that U.S. VCs prefer to invest in countries with the same law tradition (Guler and Guillén 2010a) and that bilateral flows are much smaller between countries whose legal institutions are distant than between countries whose legal institutions are similar (Aizenman and Kendall 2008). In addition to legal distance, cultural differences affect economic interactions. The recent literature has shown that cultural differences impair communication and increase failure rates in cross-border mergers (Weber and Camerer 2003, Weber et al. 1996). Cultural differences also influence how banks design borrowers' loan conditions (Giannetti and Yafeh 2010) and they determine how direct investors enter foreign markets (Kogut and Singh 1998). If the VC is not familiar with the PC country's legal and cultural institutions, it is more difficult for him to transfer and enforce the contractual and non-contractual mechanisms he typically uses in his home country to his foreign PCs.

The extent to which geographical and institutional distances affect VCs' cross-border investments likely depends on the way how VCs participate in these deals. They may invest in a foreign PC alone. Then they do not have to share benefits from these cross-border investments, but they also have to carry all costs arising from geographical and institutional distances between their home and the PC country. Alternatively, foreign VCs may team up with local VCs. Local VCs may not only provide the foreign VC with access to promising investment opportunities, but they may, as compared to standalone deals, also diminish the degree of agency problems and the foreign VC's transaction costs when the local VC monitors and supports the PC. Thus, syndication with a local VC is likely to reduce the obstacles of geographical and institutional distances foreign VCs face. Consequently foreign VCs are expected to invest over longer distances if a local VC is on board and over shorter distances if they invest alone. Hence, we postulate

Hypothesis 1. Longer geographical and institutional distances between the potential foreign VC and a PC ...

a) decrease his participation likelihood.

b) decrease his participation likelihood less when he syndicates with a local VC than when he invests alone.

VCs differ in experience, which determines their ability to exploit promising investment opportunities abroad and to manage the costs of investing abroad. We follow the recent literature (Sorenson and Stuart 2001) and distinguish between general and specific experience. Larger general experience increases the VCs' likelihood to invest, even outside the countries in which they have accumulated experience, for at least three reasons. First, the traditional learning perspective (for an overview see Barkema and Schijven 2008) suggests that VCs profit from accumulated general experience they gathered in their previous investments as they may use some of the acquired general skills in future 
deals. Even if some aspects of deal selection differ across countries, a part of the selection process of any PC involves aspects of the business plan evaluation not specific to any particular country. Similarly, some aspects of monitoring and support require knowledge specific to a particular country, but others likely apply to PCs located everywhere. With increasing experience, VCs' ability to perform these tasks at a geographical distance improves and they will more likely dare to cross borders. Second, beyond their own know-how, experienced VCs may have developed relationships with other VCs who have experience in foreign countries and who may provide them with access to promising investment opportunities in these countries. In addition, such network embeddedness may render screening, monitoring and support of foreign PCs easier. Third, VCs with large general experience may more likely be assessed by foreign PCs than VCs with small experience because PCs benefit from the certification and value-adding role of experienced VCs (Hsu 2004). Empirical studies lend support to these arguments. As an example, Powell et al. (2002), who investigate U.S. VCs' local and non-local investments in biotech firms, find that VCs who invest both locally and non-locally are those who have larger general experience.

The three above arguments for why general experience matters for VCs' participation in cross-border deals are valid for specific within-country experience as well and should even apply more strongly. VCs will, according to the learning perspective, profit from their experience in deal selection, screening, monitoring and support within the particular PC country because they are more familiar with particular local practices and habits. Also a foreign VC who is embedded in local country networks is more likely to be invited by local VCs to participate in a deal than a VC who invests in the PC country for the first time. Finally, a foreign VC who has within-country experience will more likely be recognized by PCs from this country and will receive more business proposals from local PCs. Recent empirical literature demonstrates that not only general but also specific experience is important when VCs have to overcome obstacles generated by distances. For example, a U.S. VC's cross-border experience improves his entry chances into foreign countries (Guler and Guillén 2010a, 2010b) and a U.S. VC’s within-industry experience determines the geographical and industrial composition of his domestic investments (Sorenson and Stuart 2001).

VCs' general and within-country experience likely affects the manner in which VCs participate in cross-border deals. A cross-border stand-alone deal typically requires both general and within-country experience since they are necessary to gain access to deals in a specific foreign country and to successfully screen, monitor and support the PCs. Therefore, foreign VCs with smaller general and smaller within-country experience need to rely more strongly on local VCs than foreign VCs who have large general and within-country experience and who therefore can more easily find profitable investment opportunities and handle agency problems with the PC themselves. Hence, we postulate

Hypothesis 2. Larger general and within-country experience of the potential foreign VC...

a) increases his participation likelihood.

b) increases his participation likelihood less when he syndicates with a local VC than when he invests alone. 
While the idea of syndication with a local VC as a way to gain access to cross-border deals is appealing, the underlying story is much more complex because of the costs and benefits associated with syndication. Venture capital syndication is viewed as a tool to combine various resources from syndicate members (e.g., Bygrave 1987, Manigart et al. 2004). Syndication delivers a second opinion on the future prospects of the company, thus being useful in the screening phase and limiting the risk of funding bad deals (e.g., Lerner 1994, Casamatta and Haritchabalet 2007). It creates an additional value through better monitoring and support during the investment phase (e.g., Cumming and Walz 2010, Brander et al. 2002, Tian 2009). It reduces VCs' risks and increases their portfolio diversification because they may spread their limited resources over more companies (e.g., Manigart et al. 2004). While syndication among local VCs is expected to give rise to all these benefits, syndication with a foreign VC may be even more beneficial to the local VC. Cross-border cooperation may raise the PC value as both VCs may have access to different business ecosystems and may thus combine complementary resources. For example, foreign VCs may play a key role in the PCs' internationalization efforts because the PCs may profit from the VCs' access to foreign human capital and business networks and from their knowledge of foreign product and capital markets. Also, through cross-border syndication and the reciprocal nature of relationships in the venture capital industry, local VCs may gain access to future deal flow generated by the foreign VC.

However, syndication is a complex process that will probably give rise to new agency problems emerging from information asymmetries within the syndicate (Wright and Lockett 2003). These problems are potentially aggravated when VCs come from different countries and as the distance between both VCs increases for at least three reasons. First, the local VC, who possesses more information about the quality of the deal, may be inclined to take a less informed foreign VC on board for low quality deals only. Thus, the foreign VC may suffer from adverse selection. Second, syndication may result in moral hazard and free riding problems since the distant, less informed VC is not able to observe the local VC's efforts in monitoring and support. Third, transaction costs will increase with increasing distance. In summary, finding syndication partners at long distances might substantially raise information costs whereas local syndication is much easier (Hochberg et al. 2007). One mechanism which helps reduce information and agency problems within a syndicate is trust based on joint investments in the past (e.g., Pichler and Wilhelm 2001, Gopalan et al. 2008 and Cai 2009 for empirical studies; Chemmanur and Tian 2009 or Tykvová 2007 for theoretical models). If both VCs recently experienced a successful cooperation within a syndicate, they will know each other, trust each other and will be willing to cooperate again. Empirical literature demonstrates that if two VCs have invested together in the past, this positively affects their propensity to syndicate again in future deals (e.g., Hochberg et al. 2007, Chemmanur and Tian 2009). Hence, our third hypothesis is about repeated relationships in cross-border deals. We postulate

Hypothesis 3. The potential foreign VC's participation likelihood increases when he has invested with the participating local VC in the past. 
Local VCs who invite other (local or foreign) VCs to participate in deals differ in their experience and their experience level will affect the syndicate structure. Experienced local VCs will be better able to design and manage the syndicate than their inexperienced counterparts. This will reduce costs and mitigate potential agency conflicts between the VCs. Moreover, experienced local VCs will be better able to perform information gathering and processing and may therefore more accurately signal the PC’s quality to less informed syndication partners than inexperienced local VCs. Finally, experienced local VCs may better monitor and support the PC than their inexperienced counterparts so that the syndication partner of an experienced local VC will be less actively involved in the PC monitoring and support. Because of all these reasons, the local VC's experience moderates the negative effects that syndication partner's distance has on this partner's participation likelihood. VCs may dare to invest over long distances when they can rely on the experience of the local VCs. To put it differently, distance may matter less when an experienced rather than an inexperienced local VC manages the syndicate. Hence, we predict

Hypothesis 4. Longer geographical and institutional distances between the potential syndication partner and a PC ...

a) decrease his participation likelihood.

b) decrease his participation likelihood less strongly when the local VC is experienced than when the local VC is inexperienced.

While foreign VCs with small general and small within-country experience need to rely more strongly on local VCs than foreign VCs who have large general and within-country experience, it must be questioned which local VCs invite these inexperienced partners to participate in joint deals. Recent theoretical literature suggests that the choice of syndication partners depends on the VC's own experience. In the model by Casamatta and Haritchabalet (2007), VCs screen projects to generate an information signal about the true quality of the PC. The precision of this signal increases as a VC's experience increases. Syndication allows the VC to obtain a second evaluation but it also gives rise to costs, which substantially depend on the VCs' experience. The predictions of Casamatta and Haritchabalet's model are that inexperienced VCs syndicate their deals, while experienced VCs syndicate either with experienced VCs or forgo syndication. Also, Cestone et al. (2007) argue for homogenous syndicates regarding experience. Obviously, VCs with small experience would like to join syndicates led by highly experienced VCs in order to profit from their know-how and their screening, monitoring and value-adding abilities which they may lack. However, experienced VCs prefer to syndicate with experienced VCs because they would not profit much from cooperation with inexperienced VCs who would contribute far less tangible and intangible resources than their experienced counterparts (e.g., Dimov and Milanov 2010). Highly experienced local VCs are likely to invite syndication partners whom they believe to be able to fulfil the tasks of value-adding and second opinion properly, i.e., they will choose investors with large general and within-country experience. Hence, we postulate 
Hypothesis 5. Larger general and within-country experience of the potential syndication partner... a) increases his participation likelihood.

b) increases his participation likelihood more strongly when the local VC is experienced than if the local VC is inexperienced.

\section{DATA AND METHODS}

\section{Data on Cross-border Venture Capital Deals}

We identify worldwide venture capital deals and all VCs who participate in them from the Bureau van Dijk Zephyr database. Appendix 1 provides details on how we extracted our dataset from this database and adjusted it for our purposes. Our final dataset contains 23,826 deals completed between the beginning of 2000 and the end of 2008 and 58,377 links between VCs and completed deals within the same period. A link is a connection of each individual VC participating in a deal to this deal. For example, a deal financed by three VCs contains three VC-PC links.

Figure 1 aggregates the number of local, intra- and intercontinental VC-PC links by continents. We classify a link as local when the VC has his headquarters in the same country as the PC. With more than 34,000 links in the period 2000-2008, local links of Northern American VCs (including the United States and Canada) constitute the largest figure by far, followed by European VCs with nearly 11,200 links to local PCs. There is a high intensity of intracontinental connections within Europe, with more than 3,400 cross-border VC-PC links. The bulk of intercontinental links take place between Europe and the United States in both directions, with more than 2,600 links of European VCs to U.S. PCs and nearly 1,600 links in the opposite direction.

\section{Figure 1 goes about here}

Table 1 (Panel A) shows the number and volume of local and cross-border deals VCs carry out in each country. In local deals, all VCs are located in the country of the PC. In cross-border deals, at least one VC is located outside the PC country. The by far highest number of venture capital-backed PCs is located in the United States. Here, we count 9,370 local and 2,854 cross-border deals, resulting in an internationalization share (number of cross-border to total deals) of $23 \%$. The country with the second largest VC industry, the United Kingdom with 1,540 local and 1,214 cross-border deals, has an aboveaverage internationalization share of $44.1 \%$. While the average worldwide internationalization share is $33.5 \%$ based on the number of deals, it amounts to $49.8 \%$ based on the volume. These figures underline the fact that cross-border deals are larger, on average, than local deals. Table 1 (Panel B) depicts bilateral cross-border VC-PC links for selected countries (with the highest number of crossborder links) and, for comparison purposes, the number of local links is presented at the diagonal. The strongest connection is found between the United States and the United Kingdom, with 663 links between U.S. VCs and U.K. PCs, and 923 links in the opposite direction. The comparison between deal count (Panel A) and link count (Panel B) gives first insights into syndication intensities. For instance, on average, local deals in the U.S. consist of more than 3 VCs (9,370 local deals with 32,356 local links), while local deals in Sweden consist of less than 2 VCs (380 local deals with 709 local 
links). In Germany cross-border deals have more than 1.6 foreign VCs (390 cross-border deals with 654 cross-border links), while in the United Kingdom they have only 1.1 foreign VCs on average (1,214 cross-border deals with 1,337 cross-border links).

Table 1 goes about here

Table 2 provides further insights into aggregate internationalization and syndication patterns. In total, we count 15,879 local deals, 7,474 of which are local stand-alone deals and 8,405 are syndicated among local VCs. We count 7,947 cross-border deals, 2,779 of which are cross-border stand-alone deals, 645 are cross-border deals financed by syndicates of foreign VCs, and 4,523 are cross-border deals financed by a foreign-local syndicate. It becomes obvious that VCs tend to collaborate with local VCs when crossing borders. Internationalization and syndication are related to company and deal characteristics. Local deals take place in younger PCs than cross-border deals, and syndicated deals take place in younger PCs than stand-alone deals. Local deals have smaller volumes than cross-border deals, and syndicated deals typically have larger volumes than stand-alone deals. The number of syndicate members differs across the different types of syndicated deals. The median syndicate size is 3 for local syndicates, 4 for foreign-local syndicates, and 2 for foreign syndicates. Foreign-local syndicates typically contain more local than foreign VCs (2 local and 1 foreign VCs in the median deal). In the median deal of foreign syndicates, the foreign VCs come from two different countries.

Table 2 goes about here

Figure 2 depicts all links within venture capital syndicates, distinguishing between local, intracontinental and intercontinental VC links. Each connection between any two VCs counts as one link. As an example, a syndicate consisting of three VCs (A, B, and C) contains three links: between A and B, B and C, and A and C. From Figure 2 we infer that VCs syndicate very actively, not only across borders, but also across continents. Not surprisingly, cross-border syndication is much stronger in Europe (3,249 links) than in North America (1,543 links). In Europe, 75\% of all syndicates consist of VCs from different countries, many of them even being intercontinental syndicates, in particular with North American VCs (6,808 links).

Figure 2 goes about here

Dependent Variables and Econometric Models

Our five hypotheses describe different factors and their interactions which we believe to affect the likelihood that a potential VC participates in a given deal. Unfortunately, these five hypotheses cannot be tested simultaneously in a single estimation model analyzing whether or not a potential VC participates in a deal. The reason is that studying how a local VC's presence affects the likelihood of a foreign VC's participation requires investigating the potential VC's participation likelihood in crossborder deals for which only foreign VCs as potential syndication partners are considered. However, studying how the local VCs' experience affects how they choose their syndication partners requires investigating the potential VC's participation likelihood in syndicated deals for which not only foreign, but also local VCs as potential syndication partners are considered. Therefore, we set up two 
different estimation models. The first one models the participation in cross-border deals. This model allows us to investigate how the presence of a local VC influences the participation of foreign VCs (Hypotheses 1, 2 and 3). The second model analyzes the participation in syndicated deals, which allows us to investigate how the local VC's experience influences the participation of potential syndication partners (Hypotheses 4 and 5).

In the first model, which estimates VC's participation in cross-border deals, we include all types of cross-border deals carried out between 2003 and 2008:i stand-alone deals of foreign VCs, deals financed by foreign syndicates, and deals financed by foreign-local syndicates. We then combine each of these cross-border deals with all potential (participating and non-participating) VCs who are located outside the country in which the deal takes place. Thus, we focus only on potential foreign VCs. Therefore, the participating local VCs (in deals financed by foreign-local syndicates) are not included as potential VCs in their own deals. The dependent variable equals one if a foreign VC participates in this cross-border deal (participating potential VC), and zero otherwise (non-participating potential VC). The combination of all cross-border deals with all potential (participating and non-participating) foreign VCs delivers more than 3.8 million observations. The number of observations for each deal varies because the number of potential foreign VCs which could potentially participate in this deal differs depending on the country in which the deal takes place. For example, since most VCs are located in the United States, the number of potential foreign VCs is much lower when the deal takes place in the United States than when it takes place in other countries.

In the second model, which estimates VC's participation in syndicated deals, we include deals financed by foreign-local syndicates and local syndicates. We then combine each of these syndicated deals with all (local and foreign) potential (participating and non-participating) syndication partners. We focus on the likelihood to be invited by the local VC to become a partner in a syndicated deal. Consequently, we include all other VCs (except the participating local VC) as potential syndication partners. The dependent variable equals one if a potential syndication partner participates in this syndicated deal, and zero otherwise. If we have two or more participating local VCs in one deal, we consider the VC who is located most closely to the PC the "local" one (who is assumed to invite the others). ${ }^{\mathrm{ii}}$ In the second model we obtain more than 7.6 million observations. Since the sample of potential syndication partners is of the same size for each deal and does not vary with the country in which the deal takes place (all VCs in the dataset with the exception of the participating local one), the number of observations is identical for each deal.

To estimate the likelihood of a VC participating in either cross-border (first model) or syndicated (second model) deals we employ conditional logit models (Chamberlain 1980, Andersen 1970) since we have multiple observations for each deal (equal to the number of potential VCs in each deal). The conditional logit specification provides a semi-parametric estimation of the logit model, which allows us to control for unobservable deal, company, industry, and country characteristics without having to estimate the individual deal fixed effects. The effects of all deal-specific characteristics (such as deal value and the year in which the deal takes place), all company-specific characteristics (such as age), all industry-specific characteristics (such as the degree of asset tangibility in this industry) and all 
characteristics of the country in which the PC is located (such as the availability of profitable investment opportunities), which might affect risk-return profiles and thus the investment and syndicate decisions, are included in the individual deal fixed effects. The individual deal fixed effects also capture deal characteristics related to our two central issues, namely the participation of a local VC and this VC's experience, which both do not vary over a single deal. A cross-border deal either has or does not have a participating local VC (first model). In a similar vein, a syndicated deal either has an experienced or an inexperienced participating local VC (second model). Consequently, we cannot include a dummy for the local VC's participation or the local VC's experience. To measure how the local VC's participation and the local VC's experience influence participation likelihood, an alternative approach is warranted, which we outline next.

In our first model, we interact a dummy variable that equals one if a local VC participates (and zero otherwise) with the geographical distance between the potential foreign VC and the PC. ${ }^{\mathrm{iii}}$ This interaction term allows us to investigate how the local VC's presence affects the participation of foreign VCs coming from different geographical and institutional distances and having different levels of general and within-country experience (Hypotheses $1 \mathrm{~b}$ and $2 \mathrm{~b}$ ). In our second model, we interact the local VC's experience with the geographical distance between the potential syndication partner and the PC. This interaction term allows us to investigate how the local VC's experience affects the participation of (local or foreign) syndication partners from different geographical and institutional distances and with different levels of general and within-country experience (Hypotheses $4 b$ and $5 b$ ). We evaluate the impact of the potential VC's distance and experience separately for the situation with/without a local VC (first model) and for the situation with an experienced/inexperienced local VC (second model) since we cannot infer from the estimated interaction-term coefficients whether an increase in a variable increases or decreases the likelihood of a potential VC's participation (Ai and Norton 2003).

\section{Independent Variables}

To measure the geographical distance between each potential VC and each PC, we use individual address data on the zip code, city, and country of all VCs and PCs. From http://www.batchgeocode.com/, we obtain the latitude and longitude for the center of each zip codecity-country combination. We employ Vincenty's (1975) formula ${ }^{\text {iv }}$ and calculate the distance between centers of the two zip code - city - country combinations for each potential VC-PC pair. We only include deals in our analyses for which we are able to obtain the geographical distances between the PC and each of the VCs participating in this deal.

Table 3 indicates that, on average, the foreign VC is located approximately 2,700 miles from the PC. The median distance between the foreign VC and the PC is 1,200 miles for stand-alone deals whereas it amounts to more than 3,200 miles when a local VC participates in the deal. These numbers support the view expressed in Hypothesis 1 that foreign VCs overcome the obstacles of distance by syndicating with local VCs. In deals in which local and foreign VCs form a syndicate, the median distance between the local VC and the PC is 22 miles. Throughout the empirical analysis, we use the 
logarithm of the geographical distance to capture its non-linear effect on cross-border activity documented in earlier studies (e.g., Grinblatt and Keloharju 2001).

We employ several variables to capture institutional distance. We use a dummy variable same law which equals one if the two countries share the same law tradition, and equals zero otherwise.

Countries' law traditions are based on the categorization by La Porta et al. (1998) who distinguish five law traditions (English, French, German, Scandinavian, and Socialist). Table 3 shows that the foreign VC is located in a country with the same law tradition as the country in which the PC is located in $48 \%$ of deals in which foreign and local VCs syndicate (reflecting the strong investment activity and syndication tendency between U.S. and U.K. VCs), in 35\% of stand-alone deals and in $42 \%$ of deals syndicated among foreign VCs only. Moreover, we employ legal distance measured as the difference in the two countries' levels of the legality index (based on Berkowitz et al. 2003 and employed in the context of VC by e.g., Cumming and Walz 2010) and cultural distance measured as Hofstede's power distance (as, e.g., Giannetti and Yafeh 2010). Table 3 indicates that deals in which foreign and local VCs syndicate exhibit, on average, shorter legal and cultural distances than stand-alone deals.

We follow the recent literature (e.g., Guler and Guillén 2010a and 2010b, Sorenson and Stuart 2001, Cumming and Dai 2010) and measure general and within-country experience as past deal counts. To capture VCs' time-varying general experience we count the number of each VC's deals in the previous three years. Table 3 reveals that VCs who participate in cross-border deals have larger experience than VCs who invest locally. The median VC's general experience is 4 in local stand-alone deals, 10 in local syndicates, 17 in cross-border stand-alone deals, 11 in foreign-local syndicates and 7 in foreign syndicates. These numbers also reveal the different attitudes of experienced VCs towards syndication in local and cross-border deals. While stand-alone local deals are carried out by inexperienced VCs, large general experience seems to be necessary when VCs invest alone in cross-border deals. In addition, Table 3 suggests that international syndicates are set up by more experienced VCs than local syndicates. The median and the mean experience of the closest local VC in cross-border deals are higher than the one of the closest VC in local deals. The median experience of the closest local VC is 11 in local syndicates, whereas it is 13 in foreign-local syndicates. The closest local VC typically has higher general experience than other syndicate members.

To capture the time-varying within-country experience, we classify foreign VCs as either newcomers or old hands. If the foreign VC has not invested in the country under consideration during the previous three-year window, the dummy variable newcomer equals one, and zero otherwise. If the foreign VC has invested in the country under consideration during the prior three years, the dummy variable old hand equals one, and zero otherwise. Newcomers, who invest in a country for the first time (or whose latest investment in this country lies far in the past), are supposed to face higher obstacles than old hands, who already possess valuable within-country experience, contacts and, in some cases, even local offices or subsidiaries in the PC country. Table 3 reveals that $48 \%$ of VCs in stand-alone crossborder deals, $47 \%$ of foreign VCs in foreign-local syndicates and 63\% of VCs in foreign syndicates are newcomers. 
Due to data availability we cannot capture other factors which may affect how VCs invest across borders. For example, those VCs who opened subsidiaries or offices in foreign countries in which they invest may be located very closely to their PCs, rendering the geographical distance between their headquarters and the PC irrelevant for their investment and syndication decisions. Meuleman and Wright (2011) use a dummy variable capturing the existence of local offices but, surprisingly, do not find any significant effect of this variable on the likelihood that a foreign private equity investor syndicates the deal with a local one. Unfortunately, we cannot follow their strategy since we do not have information on whether, at the date of the particular investment, the potential VC has a subsidiary or a local office in the PC country. However, we believe that our dummies newcomer and old hand at least partially account for these effects.

To construct a time-varying measure of repeated relationships, we check whether VCs carried out a joint deal during the previous three-year window. ${ }^{\mathrm{v}}$ We use a dummy variable repeated which equals one if the potential VC has invested together with the participating local VCs in the past three years. $59 \%$ of all syndicated deals are formed on the basis of repeated relationships, this fraction being the largest (67\%) in foreign-local syndicates (Table 3). These percentages may overrate the existence of repeated relationships because as many syndicates include more than two VCs, some syndicates may consist of some VCs with and other VCs without repeated relationships to each other. As an example, in a syndicate consisting of three VCs, two of them may have invested together in the past and the third VC may join this syndicate without having invested together with either of the VCs. Therefore, we also depict repeated relationships based on the participating VCs: 54\% of VCs join a syndicate with a repeated relationship to one of the other syndicate members. Again, the fraction of VCs with repeated relationships is highest within deals financed by foreign-local syndicates (58\%).

\section{Table 3 goes about here}

Appendix 2 provides definitions and sources of all variables we use.

\section{RESULTS}

\section{Participation in Cross-border Deals}

Table 4 delivers marginal effects of conditional logit estimations for the VC's participation likelihood in cross-border deals where the deal fixed effect is set equal to zero. In Panel A, we evaluate the marginal effects at the sample means of all variables except for dummy variables for which we evaluate them by changing the variable from 0 to 1 . Panel B delivers marginal effects conditional on the absence of a local VC (local dummy is set to 0 ), while Panel C delivers effects conditional on the presence of a local VC (local dummy is set to 1 ).

Model 1 includes all cross-border deals and thus is based on all combinations of cross-border deals with all potential foreign VCs. Panel A suggests that the geographical distance between the potential VC and the PC significantly decreases the likelihood of this VC's participation. Given that all variables are at their means, the likelihood of the VC's participation decreases by 0.21 percentage 
points when its distance from the PC doubles. ${ }^{\mathrm{vi}}$ A switch from a different to the same law tradition increases the likelihood of participation by 0.5 percentage points. Legal distance matters as well, but its statistical significance is low, while cultural distance does not have any significant effect on participation likelihood, which may be due to the fact that the variables same law, legal distance and cultural distance are highly correlated. Thus, consistently with Hypothesis 1a, we find evidence for a discouraging impact of VC's geographical and institutional distances on his participation in crossborder venture capital deals.

Comparing the marginal effects from Panels B and C (in Model 1) indicates that the marginal effect of the geographical distance depends on whether or not the foreign VC teams up with a local VC. A doubling in the geographical distance between the potential foreign VC and PC decreases his participation likelihood by 0.07 percentage points when he syndicates with a local VC and by 0.28 percentage points when he does not syndicate with a local VC. A local VC thus moderates the negative effect of geographical distance on the likelihood of participation. Not only geographical distance, but also same law and legal distance have a weaker effect when a local VC is involved. For example, having the same law tradition increases the participation likelihood by 0.2 percentage points when the potential foreign VC syndicates with a local VC and by 1.1 percentage points when he does not team up with a local VC. These findings support Hypothesis $1 \mathrm{~b}$.

VCs' general and within-country experience shapes the likelihood to participate in cross-border deals as expected. The likelihood of the VC's participation increases by 0.28 percentage points when the VC's general experience doubles. Being a newcomer (having no within-country experience) reduces the likelihood of participation by almost 5 percentage points. These results lend support to Hypothesis 2a.

The marginal effects of potential VCs' general as well as within-country experience on the participation likelihood are much weaker when a local VC is involved. This finding indicates that VCs who invest across borders without a local VC need a much larger experience than those VCs who rely on local VCs. To put it differently, inexperienced VCs and newcomers profit most from cooperation with local VCs. For example, a newcomer's participation probability is about 10 percentage points lower compared to old hands when a local VC is absent, while it is only 2 percentage points lower when the newcomer syndicates with a local VC. This result indicates, in line with Hypothesis 2b, that VCs without general or within-country experience have more difficulties than experienced VCs to participate in cross-border deals when a local VC is absent.

Syndication with a local VC does not instantly solve all problems that arise when VCs invest over long distances because syndication is likely to give rise to new search and transaction costs and to create new agency problems. For example, it is questionable whether the search costs of finding a local VC, with whom the foreign VC may invest, over long distances are lower than the search costs of finding an investment opportunity over long distances. However, search costs of finding a local VC, the transaction costs and the extent of new agency problems within the syndicate will be lower if both VCs interact repeatedly. In line with these arguments, we find that the participation likelihood of potential foreign VCs who have previously invested together with one of the participating local VCs is 
1.6 percentage points higher than the one of VCs who do not have a repeated relationship. This result supports Hypothesis 3 stating that a potential VC's repeated relationships to a participating local VC increase the likelihood that this potential VC participates in this cross-border deal.

\section{Table 4 goes about here}

This last finding does not imply that repeated relationships to local VCs really work over long distances since the marginal effect is evaluated at the sample mean. To investigate this issue, we evaluate the marginal effect of repeated relationships to a local VC for different distance percentiles. We depict these marginal effects (including a two-sided five percent confidence interval) in Figure 3. The marginal effect of repeated relationships to a local VC on the potential VC's participation likelihood is statistically significant at all distance deciles and it declines as the distance increases. At almost the maximum distance within Europe, which is the 4th distance decile in our data, it shows a buckle. At the $10 \%$ distance decile, the existence of repeated relationships to a participating local VC increases the participation likelihood by 3 percentage points. At the $90 \%$ distance decile, the effect reduces by 1.8 percentage points to 1.2 percentage points, but it remains significant. Thus, repeated relationships work over long geographical distances; although they are more effective over short distances.

\section{Figure 3 goes about here}

We assess whether our results hold across different deal volumes and PC ages. While in Model 1 the effects of these deal- and PC-related variables have been included in the deal fixed effects, in Models 2-5 we investigate whether these variables influence how distance, experience and repeated relationships affect participation likelihoods. Deals with a small volume have a lower syndication necessity than large deals because small deals have a lower diversification potential. Local VCs might only invite foreign VCs to participate in a deal when the deal has a large syndication necessity. Deals taking place in old PCs in which information asymmetries are less pronounced than in young PCs make a second opinion less worthy and therefore have a lower syndication necessity. Therefore, we break our sample either into small deals (second model) and large deals (third model), or into young PCs (fourth model) and old PCs (fifth model). Again, we evaluate the marginal effects at the sample means (Panel A), conditional on the absence of the local VC (Panel B) and conditional on the presence of the local VC (Panel C). By and large the results from these subsamples lead to the same conclusions and lend support to our hypotheses. One exception is the marginal effect on distance in the third model in Panel B, which is only significant at the $13.5 \%$ level.

Two findings from these subsample regressions deserve special attention. First, our results indicate that it is very difficult for inexperienced foreign VCs to invest in large deals without a local VC. This is reflected in the high marginal effects of general and within-country experience in large deals without a local VC (Model 3 in Panel B). In large deals, when the potential foreign VC's general experience doubles, the likelihood to participate increases by 3.2 percentage points when no local VC participates, but only by 0.27 percentage points when a local VC invests as well. In addition, in large deals and when no local VC invests, newcomers have a nearly 30 percentage points lower likelihood 
to participate than old hands. If a local VCs is on board, this negative effect reduces to 3.6 percentage points only.

Second, it is noteworthy that the marginal effects of repeated relationships on the participation likelihood in cross-border deals behave quite similarly on different distance deciles in the two subsamples of deal volume and the two subsamples of age (see Figure 4) to the ones we received for the full sample. The marginal effects in the subsamples are always significant for all distance percentiles. Note that the value of the highest distance percentile is similar across the various subsamples since we construct it on the distance of the participating as well as non-participating VCs. However, the size of the marginal effects of repeated relationships differs systematically between deals with a small and a large deal volume: The chances to participate in a cross-border deal on the basis of a repeated relationship are higher when the deal volume is larger.

\section{Figure 4 goes about here}

\section{Participation in Syndicated Deals}

Table 5 delivers marginal effects of conditional logit estimations for the VC's participation likelihood in syndicated deals where the deal fixed effects are set to zero. In Panel A, we evaluate the marginal effects at the sample means of all variables except for dummy variables for which we evaluate them by changing the variable from 0 to 1 . In Panel B marginal effects of potential VC's participation likelihood are conditional on an inexperienced local VC (local VC's experience is set to its value at the 25\% percentile), while in Panel C they are conditional on a highly experienced local VC (local VC's experience is set to its value at the $75 \%$ percentile).

Model 1 includes all syndicated deals and thus is based on all combinations of syndicated deals with all potential VCs. Panel A suggests that the geographical distance between the potential VC and the PC significantly decreases the likelihood of this VC's participation in syndicated deals. This finding supports Hypothesis 4a. The results in Panels B and C indicate that the local VC's experience shapes the way in which geographical distance affects the potential syndication partner's participation in syndicated deals. We find that the marginal effect of geographical distance is only negative when the local VC is inexperienced (Panel B), while it is insignificant when the local VC becomes experienced (Panel C). Thus, the geographical distance of the syndication partner becomes irrelevant when an experienced local VC manages the syndicate. This result strongly supports Hypothesis 4b.

The likelihood to participate in syndicated deals also depends on the potential VC's general and within-country experience. The results in Panel A suggest that a larger general experience increases the likelihood to be invited to participate in a syndicated deal. From the marginal effects on the dummy variables old hand and newcomer we obtain information not only on the differences between potential syndication partners who hold or lack within-country experience, but also on the differences between foreign and local VCs since all foreign VCs are classified as either newcomer or old hand. Local VCs thus constitute the reference category. Local VCs have the highest likelihood of matching because the effects of both newcomer and old hand dummies are negative and highly statistically significant. Thus, foreign VCs have to overcome obstacles local VCs do not face. The marginal effect 
of the newcomer dummy is much higher than that of the old hand dummy. This indicates that having some within-country experience reduces these obstacles, while it does not completely eliminate them. These findings support Hypothesis 5a.

A local VC's experience moderates how the potential VC's general and within-country experience affects the participation likelihood. The results on our two experience measures indicate that experienced VCs invest together. The potential syndication partner's general experience is more important when the local VC is experienced (Panel C) than when the local VC is inexperienced (Panel B). This result on the local VC's experience is further supported by the results on within-country experience. The differing marginal effects on the newcomer dummy variable in Panels B and C suggest that foreign VCs without any within-country experience have a much lower chance to be invited to participate in a deal when the local VC is experienced than when he is inexperienced. These findings lend support to Hypothesis 5b.

\section{Table 5 goes about here}

As in Table 4, we again split the sample into small and large deals as well as into young and old PCs and present the results of these models in Columns 2-5 of Table 5. These models offer the following additional insights. First, in all models, the geographical distance between the potential partner and the PC is only relevant when the local VC is inexperienced. When the local VC is experienced it does not matter whether the deal volume is small or large, or whether the PC is young or old. Thus, neither the syndication necessity nor the degree of information asymmetries proxied by PC age shape the participation likelihood of potential partners. Second, newcomers have higher chances to participate in syndicated deals if the deal volume is small rather than large. This holds irrespective of whether or not the local VC is experienced or inexperienced. Overall, newcomers have the highest chance to be invited to participate in small deals led by inexperienced local VCs.

\section{Further Robustness Checks}

We carry out additional robustness checks to obtain insights into whether the results we have presented are robust to various sources of change.

In the first set of robustness checks we re-estimate our two models for further subsamples. First, we use only first round deals, since internationalization and syndication patterns may change across investment rounds. Second, we include only those VCs that appear in the deal data in the first as well as the last year of the regression period (2003 and 2008), since some VCs may have entered or exited during this period. Therefore, we may have considered a VC as a potential investor in a specific deal although the VC was no longer or not yet in business. Third, we dismiss concerns that particular countries drive our results. We re-estimate each of our regressions 38 times, removing one country at a time from the sample. In addition, we test whether our findings change when we exclude the two countries with the largest and most important venture capital industries, the United States and the United Kingdom, simultaneously. 
In the second set of robustness checks we address the problem of our analyses being based only on those deals for which we have the PC's address as well as the addresses of all participating VCs. This might create a selection bias in our analyses if the availability of the address data is related to internationalization and syndication behavior. Therefore, instead of using the exact individual addresses, we calculate the distance between the PC and each potential VC as the distance between their countries and include all cross-border deals (first model) and all syndicated deals (second model) in these analyses.

All these robustness checks (results available upon request) broadly confirm our findings regarding the signs and also magnitudes of the marginal effects of most of our variables.

\section{Extensions}

We extend our models in several directions.

First, we employ a rare events logit model introduced by King and Zeng (2001), who argue that standard logit models can sharply underestimate the probability of rare events, and include deal volume, company age and industry dummies since this alternative approach does not model deal fixed effects. The results suggest that the participation likelihood in cross-border and syndicated deals increases as the deal value increases, underpinning that VCs syndicate when they have more diversification needs. PC age positively influences participation likelihood in syndicated deals, indicating that VCs more easily invest when the PCs is older, which might be a reflection of information asymmetries and problems which are less pronounced in old PCs than in young PCs, and that cooperating with other VCs is easier when the degree of information asymmetries is less pronounced. Also, when VCs invest across borders they aim at investing in particular industries. For example, PCs operating in the biotechnology and pharmaceutical industries have higher chances to be financed by a foreign VC than PCs operating in service industries.

Our second set of extensions considers other measures of institutional proximity besides the variables same law, legal distance and cultural distance. We use the dummy variables same language and colonial ties as alternative or additional measures of institutional proximity (e.g., Buch and DeLong 2004, Daude and Fratzscher 2008). Both of these variables are highly correlated with the other variables measuring institutional proximity (in particular with the same law dummy), which is the reason why we do not include them in our main analyses. Thus, the marginal effects of the same law dummy and other measures of institutional proximity in our main analyses likely also capture language similarities and colonial ties between countries. When we include all measures of institutional proximity simultaneously in the regressions, the marginal effects of the variable same law are lower but they remain statistically significant. Colonial ties and same language do not have a statistically significant effect. But when we include the same language variable or the colonial ties variable separately in the regressions, i.e., instead of the variable same law, they both have the expected positive and significant effect on the participation likelihood. 


\section{WHERE DOES VENTURE CAPITAL FLOW?}

In the following section, we take a different angle and analyze cross-border deals at the bilateral country level to provide an alternative test of Hypothesis 1. This alternative test is based on aggregate investment volumes rather than on participation likelihoods. If syndication with local VCs lowers the obstacles arising from geographical and institutional distances for foreign VCs, we should find the aggregate volume of deals carried out with local VCs to be less strongly affected by distances than the one of stand-alone deals. Besides offering an alternative test of Hypothesis 1, this approach allows us to obtain insights into country-specific factors that drive these flows. In the analyses at the deal level presented in the last section, we have not obtained any insights on the role of these factors because they have been included in the deal fixed effects.

\section{Dependent and Independent Variables and Econometric Models}

We estimate three models which differ with respect to the dependent variables. In the first model, the dependent variable is the annual Euro volume of all (syndicated and stand-alone) cross-border venture capital deals aggregated for each VC-PC country pair, i.e., deals of VCs located in country A (= VC country) to PCs located in country B (= PC country) as one observation and deals of VCs located in country B to PCs located in country A as another observation. To test whether VCs invest over longer geographical distances when they team up with a local VC, we employ two further models. We use the annual Euro volume of stand-alone deals in the second model and the annual Euro volume of deals syndicated with a local VC in the third model. We normalize these annual volumes (for each VC-PC country pair) by PC and VC countries' GDP since large countries evidently both attract and source more deals than small ones. Our sample period 2001-2008 ${ }^{\text {vii }}$ and our 29 sample countries ${ }^{\text {viii }}$ result in 6,496 country-pair-year observations. Since we do not observe any cross-border deals for some of the country-pair-years, we use a one-side censored Tobit model (Tobin 1958, Amemiya 1973). Censoring value is 0 .

Besides our central independent variables of interest related to the geographical and institutional distances between the VC and PC country (log geographical distance, same law, legal distance, cultural distance), we add variables that the emerging literature on VC internationalization identifies as important (Guller and Guillén 2010a and 2010b, Aizenman and Kendall 2008, Iriyama and Madhavan 2010, Schertler and Tykvová 2011). More specifically, we investigate how the availability of profitable investment opportunities, national systems of innovation, financial markets, legal institutions pertinent to venture capital activity as well as size of the local VC industries in the VC and PC country affect cross-border venture capital deals. We proxy the availability of profitable investment opportunities by the expected real GDP growth rate for the next 3-5 years (growth) and use GDP per capita (GDPcap) as a general indicator for the economic development. To measure how strong the national systems of innovation are, we use business R\&D expenditures normalized by GDP (innov). For the viability of financial markets, we employ stock market capitalization normalized by GDP (marketcap). To capture legal institutions pertinent to venture capital activity, we include a venture capital index (VCindex). Finally, we control for the size of the local venture capital industry 
measured by the number of VCs in a country normalized by GDP (VCsize). Appendix 2B provides definitions and sources of all variables used in this part of our analysis. To account for unobserved heterogeneity, we use the classical remedy, namely, we include PC and VC country dummy variables to filter out within-country time-invariant unobservable effects, and we add year dummies to filter out time-varying unobservable effects.

\section{Results}

Table 6 reports marginal effects for the unconditional expected value of left-censored Tobit estimations. Marginal effects are evaluated at the sample means. For the variable same law the marginal effects are calculated by changing the variable from 0 to 1 . The Tobit regressions for standalone cross-border deals and deals syndicated with a local VC (Models 2 and 3) are estimated in a seemingly unrelated regression framework. The Chow test reveals whether the coefficient estimates from regressions of stand-alone deals and deals syndicated with a local VC are equal.

The results for all cross-border deals (Model 1) indicate that the geographical and institutional distances between the VC and PC country are significantly and negatively related to the volume of bilateral cross-border venture capital deals between these two countries. ${ }^{\text {ix }}$ This finding suggests that the geographical and institutional distances do not only negatively affect VC's participation likelihoods but that they also determine the volume of bilateral flows between countries. Geographical and institutional distances also prove to have significant economic effects. For instance, a onestandard-deviation increase in log geographical distance (starting from the mean values of all variables and assuming that the volume of deals is positive) goes hand in hand with a decrease in the annual volume of bilateral cross-border deals of $€ 11.7$ million. This effect might seem small at first sight. However, its magnitude becomes apparent when we compare it to the mean volume of annual bilateral cross-border deals, which is $€ 48.6$ million (provided that cross-border deals are positive).

After having identified geographical and institutional distances as crucial obstacles for cross-border deals, we investigate whether syndication with a local VC diminishes these negative effects. We test whether stand-alone cross-border deals (Model 2) are more strongly affected by geographical and institutional distances than cross-border deals syndicated with local VCs (Model 3). The differences between the log geographical distance, same law as well as cultural distance coefficients on these two types of deals are highly statistically significant and go in the expected direction. Our results suggest that geographical and institutional distances to PCs create higher obstacles when VCs invest alone across borders than when they team up with a local VC.

Table 6 gives insights into which countries attract and which countries source cross-border venture capital deals. Foreign VCs strive for investments in PC countries with large business R\&D expenditures. Thus, PC countries with more developed national innovation systems, in which more innovative ideas arise and therefore more entrepreneurs demand venture capital finance, attract more funding from foreign VCs. This finding fits the outcomes of several other studies which used various proxies for the national systems of innovation, such as patenting activity and education levels (e.g., Guler and Guillén 2010a and 2010b, Aizenman and Kendall 2008). The expected growth rate in the 
VC country is negative, suggesting that when VCs have profit-making investment opportunities at home they invest less abroad. This result, however, is only significant when we differentiate between the two types of deals. Moreover, VCs investing internationally are located in countries with a high GDP per capita and high business R\&D expenditures. Probably, as Powell et al. (2002) argue, countries with developed national systems of innovations have more VCs and therefore a higher potential for cross-border outflows. A higher venture capital index is related to higher venture capital outflows, indicating that a better environment for venture capital gives rise to a higher potential for cross-border outflows, as well. This result, however, is only significant when we differentiate between the two types of deals. Finally, we find that countries with high market capitalization are able to source more cross-border deals than those with low capitalization. This finding is in line with the argument that sound financial markets encourage fundraising because they support VCs' reputation building (Jeng and Wells 2000, Bascha and Walz 2001, Gompers 1996).

\section{Table 6 goes about here}

The findings reported in Table 6 are broadly confirmed in the following robustness checks and extensions (results are available upon request). (i) We use deal counts instead of deal volumes as dependent variable. Apart from normalizing the number of deals by VC and PC country size and employing a Tobit model, we also include VC and PC country size as additional regressors and estimate a count model (e.g., Agresti 2001). (ii) We employ a double hurdle model (Cragg 1971, Jones 1989, Yen and Jones 1996, Su and Yen 2000) and a two-stage Heckman model (Heckman 1979). With these alternative approaches, we address two potential limitations of Tobit models, namely that these models are quite susceptible to misspecification and that they force one parameter to determine the effect of geographical distance on both the decision to invest abroad and the decision regarding the amount to invest. (iii) As in the last section, we use the dummy variables same language and colonial ties as additional measures of institutional proximity. Both variables affect the volume of cross-border deals positively, and this effect is again stronger for stand-alone than for locally syndicated crossborder deals. However, the effect of same language is only significant at conventional levels when we include this variable separately. (iv) We dismiss concerns that our results are dominated by particular countries by re-estimating each of our regressions 29 times, removing one country at a time from the sample. We also re-estimated our models for a sample from which we removed the United States and the United Kingdom simultaneously.

\section{SUMMARY AND OUTLOOK}

Our paper contributes to a better understanding of international venture capital investments as, to the best of our knowledge, we provide the first integrated insight into internationalization, geographical and institutional distances, general and within-country experience, cross-border syndication, and repeated relationships within a broad sample of worldwide deals. We first analyzed foreign venture capitalists' participation likelihood in cross-border deals and considered two main types of crossborder deals: stand-alone and syndicated deals. In stand-alone deals a foreign venture capitalist has to have a direct deal access whereas in syndicated deals a local venture capitalist invites a foreign venture 
capitalist to participate. We find that internationalization is not only an issue for a handful of large experienced global venture capitalists jetting across continents, while smaller, less experienced, venture capitalists are not able to exploit potential advantages stemming from internationalization. Rather, our findings suggest that syndication with local venture capitalists reduces foreign venture capitalists' obstacles arising from lacking geographical and institutional proximity to the portfolio company as well as general and within-country experience. In addition, our findings indicate that repeated relationships between foreign and local venture capitalists do exist and that they are able to reduce potential frictions which may arise between syndication partners over short as well as over long geographical distances.

Second, we analyzed venture capitalists' participation likelihood in syndicated deals and distinguished between experienced and inexperienced local venture capitalists to investigate the circumstances under which the local venture capitalists, who have access to deals, invite foreign venture capitalists to participate in these deals. Our results indicate that experienced local venture capitalists invite experienced foreign ones, while inexperienced local venture capitalists invite less experienced foreign ones. These findings suggest that inexperienced foreign venture capitalists increase their chances to invest across borders when they cooperate with local partners who are equally inexperienced. Consequently, syndication with an inexperienced local venture capitalist may be a successful way for inexperienced foreign venture capitalists to overcome the obstacles of geographical and institutional distances. This result of our analysis is of particular relevance for venture capitalists with small experience who want to expand their activities beyond their countries' borders but who do not (yet) have direct access to promising deals in foreign countries. Our results suggest that these investors may start their international expansion via syndication with inexperienced local venture capitalists. In the course of time, as they become more and more experienced and possess better contacts to other venture capitalists, they may gain access to cross-border deals on their own and may also be able to join cross-border syndicates led by more experienced investors.

Our dataset includes deals worldwide, thus offering the huge advantage of a very broad scope. However, the dataset does not contain much additional information on deal, company, and venture capitalists' characteristics. Thus, several interesting questions related to overcoming the obstacles created by distances in cross-border venture capital deals remain unexplored. As an example, our dataset does not allow us to gain insights into whether international expansion and, in particular, syndication among inexperienced investors is a profitable investment strategy. Moreover, we are aware of the fact that syndication among local and foreign venture capitalists is only one of several possible strategies to overcome obstacles from geographical and institutional distances and from the lack of experience. Local lawyers, accountants, investment bankers and strategy consultants may substitute local syndication partners. In addition, foreign venture capitalists may open their own local office, establish a local subsidiary, form a joint venture with a local venture capitalist ("long-term" syndication), invest in local funds instead of investing directly in companies ("funds-of-funds") or employ investment managers with a background in the destination country (e.g., Pruthi et al. 2009, 
Manigart et al. 2007). Examining the motives behind the choice of the appropriate strategy (or a combination of them) remains a very challenging task for future research.

\section{References}

Abdesselam, R., S. Cieply, and A.-L. Le Nadant (2008). Are corporate governance systems typologies relevant? Evidence from European transfers of ownership rights. Corporate Ownership \& Control 5(2): 87-99.

Agarwal, S. and R. Hauswald (2010). Distance and private information in lending. Review of Financial Studies 23(7): 2757-2788.

Agresti, A. (2001). Categorical data analysis (2nd ed). New York: Wiley.

Ai, C. and E. C. Norton (2003). Interaction terms in logit and probit models. Economics Letters 80: 123-129.

Aizenman, J. and J. Kendall (2008). The internationalization of venture capital and private equity. NBER Working Paper 14344.

Amemiya, T. (1973). Regression analysis when the dependent variable is truncated normal. Econometrica 41(6): 997-1016.

Andersen, E.B. (1970). Asymptotic properties of conditional maximum-likelihood estimators. Journal of the Royal Statistical Society 32:283-301.

Barkema, H. and M. Schijven (2008) How do firms learn to make acquisitions? A review of past research and an agenda for the future. Journal of Management, 34: 594-634.

Bascha A. and U. Walz (2001). Convertible securities and optimal exit decisions in venture capital finance. Journal of Corporate Finance 7: 285-306.

Berkowitz, D., K. Pistor and J. Richard (2003). Economic development, legality, and the transplant effect. European Economic Review 47(1): 165-195.

Beuselinck, C., M. Deloof and S. Manigart (2009). Private equity involvement and earnings quality. SSRN working paper. Journal of Business Finance and Accounting 36(5-6): 587-615.

Black B. S. and R. J. Gilson (1998). Venture capital and the structure of capital markets: Banks versus stock markets. Journal of Financial Economics 47: 243-277.

Bloom, N. R. Sadun and J. Van Reenen (2009). Do private equity owned firms have better management practices? CEP Occasional Paper 24.

Boschma,R. A. (2005). Proximity and innovation: a critical assessment. Regional Studies 39: 61-74.

Bottazzi, L., M. Da Rin and T. Hellmann (2009). What is the role of legal systems in financial intermediation? Theory and evidence. Journal of Financial Intermediation 18(4): 559-598.

Brander, J., R. Amit and W. Antweiler (2002). Venture capital syndication: Improved venture selection versus value-added hypothesis. Journal of Economics and Management Strategy 11(3): 423-452.

Brander, J., E. Egan and T. Hellmann (2010). Government sponsored versus private venture capital: Canadian evidence. NBER Chapters, in: International Differences in Entrepreneurship: 275320.

Brav, A., O. Brav and W. Jiang (2009). The choice of going public and going private: Evidence from UK. Working paper.

Buch, C. M. and G. DeLong (2004). Cross-border bank mergers: What lures the rare animal? Journal of Banking and Finance 28(9): 2077-2102.

Bygrave, W. D. (1987). Syndicated investments by venture capital firms: A networking perspective. Journal of Business Venturing 2: 139-154.

Cai, J. (2009). Competition or collaboration? The reciprocity effect in loan syndication. Available at SSRN: http://ssrn.com/abstract=1362454. 
Casamatta, C. and C. Haritchabalet (2007). Experience, screening and syndication in venture capital investments. Journal of Financial Intermediation 16(3): 368-398.

Cestone, G., J. Lerner and L. White (2007). The design of syndicates in venture capital. CSEF University of Salerno.

Chamberlain, G. (1980). Analysis of covariance with qualitative data. Review of Economic Studies 47(146): 225-238.

Chemmanur, T. J. and X. Tian (2009). Peer monitoring and venture capital expertise: Theory and evidence on syndicate formation and the dynamics of VC interactions. Available at SSRN: http://ssrn.com/abstract=1343116.

Coval, J. and T. Moskowitz (1999). Home bias at home: Local equity preference in domestic portfolios. Journal of Finance 54: 1-39.

Cragg, J. (1971). Some statistical models for limited dependent variables with application to the demand for durable goods. Econometrica 39: 829-844.

Cumming, D. and N. Dai (2010). Local bias in venture capital investments. Journal of Empirical Finance 17(3): 362-380.

Cumming, D. and S. Johan (2006). Provincial preferences in private equity. Financial Markets and Portfolio Management 20(4): 369-398.

Cumming, D. and U. Walz (2010). Private equity returns and disclosure around the world. Journal of International Business Studies 41: 727-754.

Cumming, D., G. Fleming and A. Schwienbacher (2006). Legality and venture capital exits. Journal of Corporate Finance 12: 214-245.

Daude, C. and M. Fratzscher (2008). The pecking order of cross-border investment. Journal of International Economics 74(1): 94-119.

Dimov, D. and H. Milanov (2010). The interplay of need and opportunity in venture capital investment syndication. Journal of Business Venturing 25: 331-348.

Fiet, J. (1995). Reliance upon informants in the venture capital industry. Journal of Business Venturing 10(3): 195-223.

Florida, R., \& Kenney, M. (1988). Venture capital and high technology entrepreneurship. Journal of Business Venturing, 3(4): 301-319.

Giannetti, M. and Y. Yafeh (2010). Do cultural differences between contracting parties matter? Evidence from syndicated bank loans. AFA 2010 Atlanta Meetings Paper. Available at SSRN: http://ssrn.com/abstract=1204202.

Gompers, P. A. (1996). Grandstanding in the venture capital industry. Journal of Financial Economics 42: 133-156.

Goossens, L., S. Manigart, and M. Meuleman (2008). The change in ownership after a buyout: Impact on performance. Journal of Private Equity 12(1) : 31 -41.

Gopalan, R., V. Nanda, and V. Yerramilli (2008). Lead arranger reputation and the loan syndication market. EFA 2008 Athens Meetings Paper. Available at SSRN: http://ssrn.com/abstract=1034044.

Gorman, M. and W. A. Sahlman (1989). What do venture capitalists do? Journal of Business Venturing 4(4): 231-248.

Grinblatt, M. and M. Keloharju (2001). How distance, language, and culture influence stockholdings and trades. Journal of Finance 54(1): 1053-1073.

Guler, I. and M. Guillén (2010a). Knowledge, institutions and organizational growth: The internationalization of U.S. venture capital firms. Journal of International Business Studies 41: 185-205.

Guler, I. and M. Guillén (2010b). Home-country networks and foreign expansion: Evidence from the venture capital industry. The Academy of Management Journal 53(2): 390-410.

Heckman, J. (1979). Sample selection bias as a specification error. Econometrica 47: 153-161.

Hege, U., F. Palomino and A. Schwienbacher (2009), Venture capital performance: The disparity between Europe and the United States. Revue de l'association française de finance 30: 7-50. 
Hochberg, Y., A. Ljungqvist, and Y. Lu (2007). Whom you know matters: Venture capital networks and investment performance. Journal of Finance 62(1): 251-301.

Hsu., D. (2004). What do entrepreneurs pay for venture capital affiliation? Journal of Finance 59(4): 1805-1844.

Iriyama, A. and R. Madhavan (2009). Understanding global flows of venture capital: Human networks as the "carrier wave" of globalization. Journal of International Business Studies 40(8): 12411259.

Ivkovic, Z. and S. Weisbenner (2005). Local does as local is: Information content of the geography of individual investors' common stock investments. Journal of Finance 60: 267-306.

Jeng, L. A. and P. C. Wells (2000). The determinants of venture capital funding: Evidence across countries. Journal of Corporate Finance 6(3): 241-289.

Jones, A.M. (1989). A double-hurdle model of cigarette consumption. Journal of Applied Econometrics 4: 23-39.

Kang, J. and J. Kim (2008). The geography of block acquisitions. Journal of Finance 63(6): 28172858.

Kang, J. and J. Kim (2010). Do foreign investors exhibit a corporate governance disadvantage? An information asymmetry perspective. Journal of International Business Studies. Journal of International Business Studies 41(8): 1415-1438.

Kaplan, S. and P. Strömberg (2003). Financial contracting theory meets the real world: An empirical analysis of venture capital contracts. Review of Economic Studies 70(2): 281-315.

Kaplan, S. and P. Strömberg (2004). Characteristics, contracts, and actions: Evidence from venture capitalist analyses. Journal of Finance 59: 2177-2210.

King, G. and L. Zeng (2001). Logistic regression in rare events data. Political Analysis 9(2): 137-163.

Kogut, B. and H. Singh (1988). The effect of national culture on the choice of entry mode. Journal of International Business Studies 19(3): 411-432.

La Porta, R., F. Lopez-de-Silanes, A. Shleifer and R.W. Vishny (1998). Law and finance. Journal of Political Economy 106(6): 1113-1155.

Lerner, J. (1994). The syndication of venture capital investments. Financial Management 23(3): 16-27.

Lerner, J. (1995). Venture capitalists and the oversight of private firms. Journal of Finance 50(1): 301118.

Lerner, J., M. Sorensen and P. Strömberg (2009). What drives private equity activity and success globally? In: World Economic Forum, Globalization of Alternative Investments Working Papers Volume 2. The Global Economic Impact of Private Equity Report 2009.

Manigart, S., A. Lockett, M. Meuleman, M. Wright, H. Landström, H. Bruining, P. Desbrières and U. Hommel (2004). Why do venture capital companies syndicate? Working Papers of Faculty of Economics and Business Administration, Ghent University, Belgium 04/226, Ghent University, Faculty of Economics and Business Administration.

Manigart, S., V. Collewaert, M. Wright, S. Pruthi, A. Lockett, H. Bruining, U. Hommel and H. Landstrom (2007). Human capital and the internationalisation of venture capital. International Entrepreneurship and Management Journal 3(1): 109-125.

Meuleman, M. and M. Wright (2011). Cross border private equity syndication: institutional context and learning. Journal of Business Venturing 26(1): 35-48.

Meuleman, M., M. Wright, S. Manigart and A. Lockett (2009). Private equity syndication: Agency costs, reputation and collaboration. Journal of Business Finance and Accounting 36(5-6): 616644.

Petersen, M. (2009). Estimating standard errors in finance panel data sets: Comparing approaches. Review of Financial Studies 22(1): 435-480.

Pichler, P. and W. Wilhelm (2001). A theory of the syndicate: Form follows function. Journal of Finance 56(6): 2237-2264.

Powell, W. W., K. W. Koput, J. and J. Bowie and L. Smith-Doerr (2002). The spatial clustering of science and capital: Accounting for biotech firm-venture capital relationships. Regional Studies 36(3): 291-305. 
Prijcker, S. De, S. Manigart, M. Wright and W. De Maeseneire (2009). The influence of international human capital and international network relationships on the cross-border investment behaviour of private equity firms. Ghent University Working Paper 2009/597.

Pruthi, S., M. Wright and K. Meyer (2009). Staffing venture capital firms' overseas operations. International Journal of Human Resource Management 20(1): 186-205.

Sapienza, H. and A. Gupta (1994). Impact of agency risks and task uncertainty on venture capitalistCEO interaction. Academy of Management Journal 37: 1618-1632.

Schertler, A. and T. Tykvová (2011). Venture capital and internationalization. International Business Review. Forthcoming.

Schoar, A. and J. Lerner (2004). Transaction structures in the developing world: Evidence from private equity. MIT Sloan Working Paper No. 4468-04. Available at SSRN: http://ssrn.com/abstract $=511202$ or DOI: $10.2139 /$ ssrn.511202

Sorenson, O. and T. E. Stuart (2001). Syndication networks and the spatial distribution of venture capital investments. American Journal of Sociology 106(6): 1546-1588.

Su, S-J. B. and S.T. Yen (2000). A censored system of cigarette and alcohol consumption. Applied Economics 32: 729-737.

Tian, X. (2009). The role of venture capital syndication in value creation for entrepreneurial firms (May 1, 2009). EFA 2007 Ljubljana Meetings Paper. Available at SSRN: http://ssrn.com/abstract=954188.

Tobin, J. (1958). Estimation for relationships with limited dependent variables. Econometrica 26(1): 24-36.

Tykvová, T. (2007). Who chooses whom? Syndication, skills and reputation. Review of Financial Economics 16(1): 5-28.

Ueda, M. (2004). Bank versus venture capital: Project evaluation, screening, and expropriation. Journal of Finance 59(2): 601-621.

Vincenty, T. (1975). Direct and inverse solutions of geodesics on the ellipsoid with application of nested equations. Survey Review 23(176): 88-93.

Weber, R. and C. Camerer (2003). Cultural conflict and merger failure: An experimental approach. Management Science 49: 400-415.

Weber, Y., O. Shenkar and A. Raveh (1996). National and corporate cultural fit in merger/acquisitions: An exploratory study. Management Science 42: 1215-1227.

Wright, M. and A. Lockett (2003). The structure and management of alliances: Syndication in the venture capital industry. Journal of Management Studies 40: 2073-2102.

Wright, M., S. Pruthi, and A. Lockett (2005). International venture capital research: From cross country comparisons to crossing countries. International Journal of Management Reviews 7(3): 135-166.

Yen, S.T. and A. M. Jones (1996). Individual cigarette consumption and addiction: A flexible limited dependent variable approach. Health Economics 5: 105-117.

Zider, B. (1998). How venture capital works. Harvard Business Review: 131-139. 
Table 1 Deals by countries

Panel A Number and volume (bn EUR) of deals carried out in each country

\begin{tabular}{|c|c|c|c|c|c|c|}
\hline \multirow[b]{2}{*}{ PC country } & \multicolumn{3}{|c|}{ NUMBER } & \multicolumn{3}{|c|}{ VOLUME } \\
\hline & $\begin{array}{c}\text { Cross-border } \\
\text { deals }\end{array}$ & $\begin{array}{c}\text { Local } \\
\text { deals }\end{array}$ & $\begin{array}{c}\text { Cross-border to } \\
\text { total deals (\%) }\end{array}$ & $\begin{array}{c}\text { Cross-border } \\
\text { deals }\end{array}$ & $\begin{array}{l}\text { Local } \\
\text { deals }\end{array}$ & $\begin{array}{c}\text { Cross-border to } \\
\text { total deals (\%) }\end{array}$ \\
\hline Australia & 201 & 92 & 68.6 & 1.231 & 0.444 & 73.5 \\
\hline Austria & 44 & 45 & 49.4 & 0.396 & 0.125 & 76.0 \\
\hline Belgium & 111 & 152 & 42.2 & 0.923 & 0.523 & 63.9 \\
\hline Brazil & 12 & 10 & 54.5 & 1.454 & 1.031 & 58.5 \\
\hline Bulgaria & 10 & 2 & 83.3 & 0.133 & na & na \\
\hline Canada & 387 & 686 & 36.1 & 6.543 & 2.142 & 75.3 \\
\hline Chile & 1 & 2 & 33.3 & 0.043 & na & na \\
\hline China & 270 & 84 & 76.3 & 4.679 & 0.677 & 87.4 \\
\hline Czech Republic & 7 & 3 & 70.0 & 0.013 & na & na \\
\hline Denmark & 107 & 112 & 48.9 & 1.298 & 0.331 & 79.7 \\
\hline Egypt & 6 & 1 & 85.7 & 0.234 & 0.030 & 88.6 \\
\hline Estonia & 6 & 3 & 66.7 & 0.004 & 0.004 & 53.8 \\
\hline Finland & 111 & 162 & 40.7 & 0.849 & 0.129 & 86.8 \\
\hline France & 503 & 1,140 & 30.6 & 21.483 & 13.553 & 61.3 \\
\hline Germany & 390 & 620 & 38.6 & 8.499 & 2.693 & 75.9 \\
\hline Greece & 1 & 9 & 10.0 & na & 0.573 & na \\
\hline Hong Kong & 17 & 2 & 89.5 & 0.564 & 0.004 & 99.3 \\
\hline Hungary & 10 & 6 & 62.5 & 0.093 & 0.005 & 95.1 \\
\hline India & 184 & 75 & 71.0 & 5.515 & 0.550 & 90.9 \\
\hline Ireland & 129 & 84 & 60.6 & 0.940 & 0.252 & 78.9 \\
\hline Israel & 298 & 198 & 60.1 & 3.200 & 1.405 & 69.5 \\
\hline Italy & 155 & 124 & 55.6 & 4.406 & 0.858 & 83.7 \\
\hline Japan & 28 & 24 & 53.8 & 5.856 & 0.235 & 96.1 \\
\hline Jordan & 1 & 1 & 50.0 & 0.106 & na & na \\
\hline Lithuania & 7 & 5 & 58.3 & 0.028 & 0.009 & 75.3 \\
\hline Luxembourg & 15 & 2 & 88.2 & 0.962 & 0.002 & 99.8 \\
\hline Malaysia & 8 & 8 & 50.0 & 0.600 & 0.016 & 97.3 \\
\hline Netherlands & 146 & 187 & 43.8 & 3.211 & 0.346 & 90.3 \\
\hline New Zealand & 9 & 20 & 31.0 & 0.035 & 0.023 & 60.5 \\
\hline Nigeria & 1 & 1 & 50.0 & 0.033 & 0.009 & 78.2 \\
\hline Norway & 77 & 80 & 49.0 & 0.843 & 0.278 & 75.2 \\
\hline Phillippines & 2 & 0 & 100.0 & 0.001 & 0 & 100.0 \\
\hline Poland & 24 & 13 & 64.9 & 0.043 & 0.010 & 80.7 \\
\hline Portugal & 26 & 21 & 55.3 & 0.416 & 0.056 & 88.2 \\
\hline Russia & 38 & 19 & 66.7 & 1.161 & 0.155 & 88.2 \\
\hline Saudi Arabia & 0 & 2 & 0.0 & 0 & na & na \\
\hline Singapore & 32 & 8 & 80.0 & 0.297 & 0.028 & 91.4 \\
\hline South Africa & 9 & 26 & 25.7 & 0.691 & 0.392 & 63.8 \\
\hline Spain & 117 & 489 & 19.3 & 5.586 & 4.472 & 55.5 \\
\hline Sweden & 244 & 380 & 39.1 & 3.146 & 0.963 & 76.6 \\
\hline Switzerland & 115 & 39 & 74.7 & 1.637 & 0.204 & 88.9 \\
\hline Thailand & 5 & 1 & 83.3 & 0.029 & na & na \\
\hline Turkey & 7 & 8 & 46.7 & 0.397 & 0.031 & 92.8 \\
\hline Ukraine & 3 & 1 & 75.0 & 0.085 & 0.022 & 79.6 \\
\hline United Kingdom & 1,214 & 1,540 & 44.1 & 14.157 & 6.904 & 67.2 \\
\hline United States & 2,854 & 9,370 & 23.3 & 53.578 & 117.193 & 31.4 \\
\hline Uruguay & 0 & 1 & 0.0 & 0 & 0.001 & 0 \\
\hline Vietnam & 5 & 21 & 19.2 & 0.033 & 0.051 & 39.0 \\
\hline Total & 7,947 & 15,879 & 33.5 & 155.432 & 156.728 & 499.8 \\
\hline
\end{tabular}


Table 1 - cont.

Panel B Number of bilateral cross-border and local links for selected countries

\begin{tabular}{lcccccccccc}
\hline PC countries & Canada & China & France & Germany & Israel & Sweden & $\begin{array}{c}\text { United } \\
\text { Kingdom }\end{array}$ & $\begin{array}{c}\text { United } \\
\text { States }\end{array}$ & $\begin{array}{c}\text { Other } \\
\text { Total CB } \\
\text { deals }\end{array}$ \\
\hline \hline Canada & 1,700 & 4 & 7 & 4 & 6 & 4 & 43 & 492 & 70 & $\mathbf{6 3 0}$ \\
China & 0 & 190 & 5 & 2 & 3 & 4 & 38 & 226 & 169 & $\mathbf{4 4 7}$ \\
France & 16 & 0 & 2,876 & 49 & 6 & 12 & 232 & 199 & 271 & $\mathbf{7 8 5}$ \\
Germany & 1 & 0 & 49 & 1,441 & 0 & 7 & 208 & 137 & 252 & $\mathbf{6 5 4}$ \\
Israel & 9 & 0 & 14 & 47 & 650 & 3 & 49 & 289 & 55 & $\mathbf{4 6 6}$ \\
Sweden & 2 & 0 & 14 & 9 & 1 & 709 & 89 & 45 & 150 & $\mathbf{3 1 0}$ \\
United Kingdom & 14 & 8 & 86 & 82 & 21 & 18 & 3,248 & 663 & 445 & $\mathbf{1 , 3 3 7}$ \\
United States & 515 & 28 & $\mathbf{2 2 6}$ & 397 & 508 & 125 & 923 & 32,356 & 1,543 & $\mathbf{4 , 2 6 5}$ \\
Other & 17 & 3 & $\mathbf{1 5 9}$ & 196 & 8 & 111 & 492 & 742 & 3,436 & $\mathbf{2 , 3 7 6}$ \\
\hline \hline
\end{tabular}

Source: Authors’ calculation from Zephyr data (2000-2008). 
Table 2 Internationalization and syndication

\begin{tabular}{|c|c|c|c|c|c|}
\hline \multirow[t]{2}{*}{ Number of deals } & \multicolumn{2}{|c|}{$\begin{array}{c}\text { Local deals } \\
\text { (all VCs are local) } \\
\mathbf{1 5 , 8 7 9}\end{array}$} & \multicolumn{3}{|c|}{$\begin{array}{c}\text { Cross-border deals } \\
\text { (at least one foreign VC) } \\
\mathbf{7 , 9 4 7}\end{array}$} \\
\hline & $\begin{array}{l}\text { Stand- } \\
\text { alone }\end{array}$ & $\begin{array}{c}\text { Local } \\
\text { syndicates }\end{array}$ & $\begin{array}{l}\text { Stand- } \\
\text { alone }\end{array}$ & $\begin{array}{l}\text { Foreign- } \\
\text { local } \\
\text { syndicates }\end{array}$ & $\begin{array}{l}\text { Foreign } \\
\text { syndicat } \\
\text { es }\end{array}$ \\
\hline Number of deals & 7,474 & 8,405 & 2,779 & 4,523 & 645 \\
\hline In \% & 31.4 & 35.3 & 11.7 & 19.0 & 2.7 \\
\hline \multirow[t]{2}{*}{ No. of links } & 7,474 & 26,731 & 2,779 & 19,675 & 1,718 \\
\hline & \multicolumn{5}{|c|}{ PC AND DEAL CHARACTERISTICS } \\
\hline Mean (median) age of the PC & $\begin{array}{l}12 \\
(6)\end{array}$ & $\begin{array}{c}6 \\
(5)\end{array}$ & $\begin{array}{l}21 \\
(10)\end{array}$ & $\begin{array}{c}6 \\
(5)\end{array}$ & $\begin{array}{c}9 \\
(5)\end{array}$ \\
\hline \multirow[t]{2}{*}{ Mean (median) deal volume (mil. EUR) } & $\begin{array}{l}11 \\
(3)\end{array}$ & $\begin{array}{l}15 \\
(9)\end{array}$ & $\begin{array}{l}31 \\
(5)\end{array}$ & $\begin{array}{c}25 \\
(15)\end{array}$ & $\begin{array}{c}34 \\
(11)\end{array}$ \\
\hline & \multicolumn{5}{|c|}{ NUMBER OF VCs } \\
\hline Mean (median) number of VCs & $\begin{array}{c}1 \\
(1)\end{array}$ & $\begin{array}{l}3.2 \\
(3)\end{array}$ & $\begin{array}{c}1 \\
(1)\end{array}$ & $\begin{array}{l}4.3 \\
(4)\end{array}$ & $\begin{array}{l}2.7 \\
(2)\end{array}$ \\
\hline Mean (median) number of foreign VCs & 0 & 0 & 1 & 1.6 & 2.7 \\
\hline \multirow{4}{*}{ Mean (median) number of local VCs } & (0) & (0) & (1) & (1) & (2) \\
\hline & 1 & 3.2 & 0 & 2.7 & 0 \\
\hline & (1) & (3) & (0) & (2) & (0) \\
\hline & \multicolumn{5}{|c|}{ NUMBER OF COUNTRIES } \\
\hline Mean (median) number of countries & $\begin{array}{c}1 \\
(1)\end{array}$ & $\begin{array}{c}1 \\
\text { (1) }\end{array}$ & $\begin{array}{c}1 \\
\text { (1) }\end{array}$ & $\begin{array}{l}2.5 \\
\text { (2) }\end{array}$ & $\begin{array}{l}1.9 \\
(2)\end{array}$ \\
\hline
\end{tabular}

Source: Authors' calculation from Zephyr data and other sources (2000-2008). 


\begin{tabular}{lcc|ccc} 
& \multicolumn{2}{c}{$\begin{array}{c}\text { Local deals } \\
\text { (all VCs are local) }\end{array}$} & \multicolumn{2}{c}{$\begin{array}{c}\text { Cross-border deals } \\
\text { (at least one foreign VC) }\end{array}$} \\
\hline \hline No. of deals & Stand-alone & $\begin{array}{c}\text { Local } \\
\text { syndicates }\end{array}$ & $\begin{array}{c}\text { Stand- } \\
\text { alone }\end{array}$ & $\begin{array}{c}\text { Foreign- } \\
\text { local } \\
\text { syndicates } \\
\text { Fond }\end{array}$ & $\begin{array}{c}\text { Foreign } \\
\text { syndicates }\end{array}$ \\
\hline \hline
\end{tabular}

\section{GEOGRAPHICAL DISTANCE BETWEEN VC and PC*}

Mean (median) distance of all participating foreign VCs in miles Mean (median) distance of all participating local VCs in miles Mean (median) distance of the closest local VC in miles

$\begin{array}{cc}- & - \\ 487 & 727 \\ (79) & (251) \\ 487 & 215 \\ (79) & (18)\end{array}$

2,724

$(1,205)$

2,774

$(3,272)$

741

(207)

266

(79)

INSTITUTIONAL DISTANCE BETWEEN VC and PC**

Same law tradition in VC and PC country

Mean (median) legal distance of the foreign VC

Mean (median) cultural distance of the foreign VC

Mean (median) general experience

Mean (median) general experience of the closest local VC

Newcomers

\begin{tabular}{cc|ccc}
- & - & $35 \%$ & $48 \%$ & $42 \%$ \\
- & & & \\
& - & 1.46 & 1.22 & 1.75 \\
- & $(0.44)$ & $(0.70)$ & $(0.84)$ \\
& - & 13.34 & 13.30 & 16.93 \\
& & $(5.00)$ & $(6.00)$ & $(12.00)$
\end{tabular}

EXPERIENCE OF VCs***

\begin{tabular}{cc|ccc}
16.2 & 21.9 & 82.2 & 24.7 & 25.7 \\
$(4)$ & $(10)$ & $(17)$ & $(11)$ & $(7)$ \\
16.2 & 25.2 & - & 27.0 & - \\
$(4)$ & $(11)$ & & $(13)$ & \\
- & - & $48 \%$ & $47 \%$ & $63 \%$
\end{tabular}

REPEATED RELATIONSHIPS BETWEEN VCs***

Fraction of syndicated deals with repeated relationships

Fraction of VCs in syndicated deals

\begin{tabular}{l|}
$56 \%$ \\
$52 \%$
\end{tabular}

$67 \%$

$41 \%$ with repeated relationships

* only for deals for which each VC's and the PC's geographical location (latitude and longitude) are available.

** only for deals for which VC country and PC country characteristics are available.

*** 2003-2008 period.

Source: Authors' calculation from Zephyr data and other sources (2000-2008). 
Table 4 Participation in cross-border deals

\begin{tabular}{|c|c|c|c|c|c|}
\hline Panel A & $\begin{array}{l}\text { Model } 1 \\
\text { All deals }\end{array}$ & $\begin{array}{c}\text { Model } 2 \\
\text { small deals }\end{array}$ & $\begin{array}{c}\text { Model } 3 \\
\text { large deals }\end{array}$ & $\begin{array}{c}\text { Model } 4 \\
\text { young PCs }\end{array}$ & $\begin{array}{l}\text { Model } 5 \\
\text { old PCs }\end{array}$ \\
\hline log distance, distXlocal & $\begin{array}{c}-0.003 * * * \\
(0.001)\end{array}$ & $\begin{array}{c}-0.002 * * * \\
(0.001)\end{array}$ & $\begin{array}{c}-0.005^{* * *} \\
(0.001)\end{array}$ & $\begin{array}{c}-0.002 * * * \\
(0.001)\end{array}$ & $\begin{array}{c}-0.003 * * * \\
(0.001)\end{array}$ \\
\hline same law & $\begin{array}{c}0.005^{* * *} \\
(0.002)\end{array}$ & $\begin{array}{c}0.004 * * \\
(0.002)\end{array}$ & $\begin{array}{c}0.010^{* * *} \\
(0.004)\end{array}$ & $\begin{array}{c}0.004^{* * *} \\
(0.001)\end{array}$ & $\begin{array}{c}0.005 \\
(0.004)\end{array}$ \\
\hline legal distance & $\begin{array}{l}-0.001 * \\
(0.001)\end{array}$ & $\begin{array}{c}-0.001 * * * \\
(0.000)\end{array}$ & $\begin{array}{l}-0.000 \\
(0.001)\end{array}$ & $\begin{array}{l}-0.001 * \\
(0.001)\end{array}$ & $\begin{array}{l}-0.002 * \\
(0.001)\end{array}$ \\
\hline cultural distance & $\begin{array}{c}-0.001 \\
(0.000)\end{array}$ & $\begin{array}{l}-0.000 \\
(0.000)\end{array}$ & $\begin{array}{l}-0.000 \\
(0.001)\end{array}$ & $\begin{array}{l}-0.000 \\
(0.000)\end{array}$ & $\begin{array}{c}-0.001 * \\
(0.001)\end{array}$ \\
\hline log experience & $\begin{array}{c}0.004^{* * *} \\
(0.001)\end{array}$ & $\begin{array}{c}0.003^{* * *} \\
(0.001)\end{array}$ & $\begin{array}{c}0.009 * * * \\
(0.003)\end{array}$ & $\begin{array}{c}0.003^{* * *} \\
(0.001)\end{array}$ & $\begin{array}{l}0.005^{* *} \\
(0.002)\end{array}$ \\
\hline newcomer & $\begin{array}{c}-0.046 * * * \\
(0.017)\end{array}$ & $\begin{array}{c}-0.034 * * * \\
(0.012)\end{array}$ & $\begin{array}{c}-0.075 * * \\
(0.036)\end{array}$ & $\begin{array}{c}-0.036 * * \\
(0.016)\end{array}$ & $\begin{array}{c}-0.053^{* *} \\
(0.023)\end{array}$ \\
\hline repeated & $\begin{array}{c}0.016^{* * * *} \\
(0.005)\end{array}$ & $\begin{array}{c}0.009 * * \\
(0.004)\end{array}$ & $\begin{array}{c}0.037 * * * \\
(0.013)\end{array}$ & $\begin{array}{c}0.014^{* * *} \\
(0.005)\end{array}$ & $\begin{array}{c}0.017 * * \\
(0.008)\end{array}$ \\
\hline \multicolumn{6}{|c|}{ Panel B: local VC is absent (local $=0$ ) } \\
\hline log distance, distXlocal & $\begin{array}{c}-0.004 * * * \\
(0.001)\end{array}$ & $\begin{array}{c}-0.003 * * * \\
(0.001)\end{array}$ & $\begin{array}{l}-0.007 \\
(0.005)\end{array}$ & $\begin{array}{c}-0.005^{* * *} \\
(0.001)\end{array}$ & $\begin{array}{c}-0.004 * * * \\
(0.001)\end{array}$ \\
\hline same law & $\begin{array}{l}0.011 * \\
(0.006)\end{array}$ & $\begin{array}{l}0.009 * \\
(0.005)\end{array}$ & $\begin{array}{l}0.051^{*} \\
(0.029)\end{array}$ & $\begin{array}{c}0.011^{* *} \\
(0.005)\end{array}$ & $\begin{array}{c}0.009 \\
(0.008)\end{array}$ \\
\hline legal distance & $\begin{array}{c}-0.003 * \\
(0.002)\end{array}$ & $\begin{array}{c}-0.003^{* *} \\
(0.001)\end{array}$ & $\begin{array}{l}-0.002 \\
(0.005)\end{array}$ & $\begin{array}{c}-0.003^{*} \\
(0.001)\end{array}$ & $\begin{array}{l}-0.003 \\
(0.002)\end{array}$ \\
\hline cultural distance & $\begin{array}{c}-0.001 \\
(0.001)\end{array}$ & $\begin{array}{c}-0.001 \\
(0.001)\end{array}$ & $\begin{array}{l}-0.000 \\
(0.005)\end{array}$ & $\begin{array}{l}-0.001 \\
(0.001)\end{array}$ & $\begin{array}{c}-0.002 \\
(0.001)\end{array}$ \\
\hline log experience & $\begin{array}{c}0.010 * * \\
(0.004)\end{array}$ & $\begin{array}{c}0.006 * * \\
(0.003)\end{array}$ & $\begin{array}{c}0.046 * * \\
(0.023)\end{array}$ & $\begin{array}{c}0.010^{* * *} \\
(0.004)\end{array}$ & $\begin{array}{c}0.008 \\
(0.006)\end{array}$ \\
\hline newcomer & $\begin{array}{l}-0.102 * * \\
(0.0411) \\
\end{array}$ & $\begin{array}{c}-0.077^{* *} \\
(0.032)\end{array}$ & $\begin{array}{c}-0.297 * * * \\
(0.1145)\end{array}$ & $\begin{array}{c}-0.103^{* * *} \\
(0.040)\end{array}$ & $\begin{array}{l}-0.084 * \\
(0.052) \\
\end{array}$ \\
\hline \multicolumn{6}{|c|}{ Panel C: local VC is present (local=1) } \\
\hline log distance, distXlocal & $\begin{array}{c}-0.001^{* * *} \\
(0.000)\end{array}$ & $\begin{array}{c}-0.001^{* * *} \\
(0.000)\end{array}$ & $\begin{array}{c}-0.003^{* * *} \\
(0.001)\end{array}$ & $\begin{array}{c}-0.001^{* * *} \\
(0.000)\end{array}$ & $\begin{array}{c}-0.001^{* *} \\
(0.000)\end{array}$ \\
\hline same law & $\begin{array}{c}0.002^{* * *} \\
(0.001)\end{array}$ & $\begin{array}{c}0.002 * * \\
(0.001)\end{array}$ & $\begin{array}{c}0.005^{* * * *} \\
(0.002)\end{array}$ & $\begin{array}{c}0.002 * * \\
(0.001)\end{array}$ & $\begin{array}{c}0.002 * * \\
(0.001)\end{array}$ \\
\hline legal distance & $\begin{array}{c}-0.001 * * \\
(0.001)\end{array}$ & $\begin{array}{c}-0.000 * * * \\
(0.000)\end{array}$ & $\begin{array}{l}-0.000 \\
(0.000)\end{array}$ & $\begin{array}{l}-0.000 * \\
(0.000)\end{array}$ & $\begin{array}{c}-0.001^{* *} \\
(0.000)\end{array}$ \\
\hline cultural distance & $\begin{array}{l}-0.000 \\
(0.000)\end{array}$ & $\begin{array}{l}-0.000 \\
(0.000)\end{array}$ & $\begin{array}{l}-0.000 \\
(0.000)\end{array}$ & $\begin{array}{l}-0.000 \\
(0.000)\end{array}$ & $\begin{array}{l}-0.000 * \\
(0.000)\end{array}$ \\
\hline log experience & $\begin{array}{c}0.002^{* * *} \\
(0.001)\end{array}$ & $\begin{array}{c}0.001^{* *} \\
(0.000)\end{array}$ & $\begin{array}{c}0.004^{* * *} \\
(0.001)\end{array}$ & $\begin{array}{c}0.001 * * \\
(0.001)\end{array}$ & $\begin{array}{l}0.002 * \\
(0.001)\end{array}$ \\
\hline newcomer & $\begin{array}{c}-0.023 * * \\
(0.010)\end{array}$ & $\begin{array}{c}-0017^{* *} \\
(0.008)\end{array}$ & $\begin{array}{c}-0.036^{*} \\
(0.019)\end{array}$ & $\begin{array}{c}-0.021 * \\
(0.011)\end{array}$ & $\begin{array}{c}-0.025^{* *} \\
(0.010)\end{array}$ \\
\hline VC country dummies & yes & yes & yes & yes & yes \\
\hline Deal fixed effects & yes & yes & yes & yes & yes \\
\hline Pseudo $R^{2}$ & 0.243 & 0.237 & 0.244 & 0.261 & 0.215 \\
\hline Number of obs. (deal-VC pairs) & $3,811,567$ & $1,499,297$ & $1,496,506$ & $2,063,507$ & $1,560,816$ \\
\hline Number of deals & 1,675 & 657 & 668 & 922 & 669 \\
\hline
\end{tabular}

${ }^{*} \mathrm{p}<0.10,{ }^{* *} \mathrm{p}<0.05,{ }^{* * *} \mathrm{p}<0.01$ (standard errors clustered at PC country and year (see Petersen 2009) in parentheses). 
Table 5 Participation in syndicated deals

\begin{tabular}{|c|c|c|c|c|c|}
\hline Panel A & $\begin{array}{l}\text { Model } 1 \\
\text { All deals }\end{array}$ & $\begin{array}{c}\text { Model } 2 \\
\text { small deals }\end{array}$ & $\begin{array}{c}\text { Model } 3 \\
\text { large deals }\end{array}$ & $\begin{array}{c}\text { Model } 4 \\
\text { young PCs }\end{array}$ & $\begin{array}{l}\text { Model } 5 \\
\text { old PCs }\end{array}$ \\
\hline log distance, distXexpLocal & $\begin{array}{c}-0.003 * * \\
(0.002)\end{array}$ & $\begin{array}{c}-0.004^{* * *} \\
(0.001)\end{array}$ & $\begin{array}{c}-0.002 \\
(0.003)\end{array}$ & $\begin{array}{c}-0.005^{* * *} \\
(0.002)\end{array}$ & $\begin{array}{l}-0.001 \\
(0.002)\end{array}$ \\
\hline same law & $\begin{array}{c}0.055^{* * *} \\
(0.014)\end{array}$ & $\begin{array}{c}0.037 * * \\
(0.016)\end{array}$ & $\begin{array}{c}0.081^{* * *} \\
(0.026)\end{array}$ & $\begin{array}{c}0.041^{* *} \\
(0.019)\end{array}$ & $\begin{array}{c}0.067 * * * \\
(0.018)\end{array}$ \\
\hline legal distance & $\begin{array}{c}-0.019 * * * \\
(0.006)\end{array}$ & $\begin{array}{c}-0.024 * * * \\
(0.008)\end{array}$ & $\begin{array}{l}-0.012 \\
(0.007)\end{array}$ & $\begin{array}{c}-0.024^{* * *} \\
(0.007)\end{array}$ & $\begin{array}{l}-0.013 \\
(0.008)\end{array}$ \\
\hline cultural distance & $\begin{array}{l}-0.007 * \\
(0.004)\end{array}$ & $\begin{array}{c}-0.001^{* *} \\
(0.000)\end{array}$ & $\begin{array}{l}-0.000 \\
(0.001)\end{array}$ & $\begin{array}{l}-0.001 \\
(0.000)\end{array}$ & $\begin{array}{c}-0.001^{* *} \\
(0.001)\end{array}$ \\
\hline log experience & $\begin{array}{c}0.063^{* * *} \\
(0.009)\end{array}$ & $\begin{array}{c}0.040 * * * \\
(0.009)\end{array}$ & $\begin{array}{c}0.103^{* * *} \\
(0.011)\end{array}$ & $\begin{array}{c}0.060 * * * \\
(0.0078)\end{array}$ & $\begin{array}{c}0.059 * * * \\
(0.010)\end{array}$ \\
\hline newcomer & $\begin{array}{c}-0.348 * * * \\
(0.044)\end{array}$ & $\begin{array}{c}-0.307 * * * \\
(0.052)\end{array}$ & $\begin{array}{c}-0.391 * * * \\
(0.039)\end{array}$ & $\begin{array}{c}-0.331 * * * \\
(0.049)\end{array}$ & $\begin{array}{c}-0.339 * * * \\
(0.045)\end{array}$ \\
\hline old hand & $\begin{array}{c}-0.059 * * * \\
(0.008)\end{array}$ & $\begin{array}{c}-0.042 * * * \\
(0.009)\end{array}$ & $\begin{array}{c}-0.076 * * * \\
(0.013)\end{array}$ & $\begin{array}{c}-0.051 * * * \\
(0.008)\end{array}$ & $\begin{array}{c}-0.060 * * * \\
(0.011)\end{array}$ \\
\hline repeated & $\begin{array}{c}0.488 * * * \\
(0.021)\end{array}$ & $\begin{array}{c}0.424 * * * \\
(0.061)\end{array}$ & $\begin{array}{c}0.527 * * * \\
(0.016)\end{array}$ & $\begin{array}{c}0.430 * * * \\
(0.032)\end{array}$ & $\begin{array}{c}0.538 * * * \\
(0.030)\end{array}$ \\
\hline \multicolumn{6}{|l|}{ Panel B: local VC is inexperienced } \\
\hline log distance, distXexpLocal & $\begin{array}{c}-0.006 * * * \\
(0.001)\end{array}$ & $\begin{array}{c}-0.005 * * * \\
(0.001)\end{array}$ & $\begin{array}{c}-0.007 * * * \\
(0.002)\end{array}$ & $\begin{array}{c}-0.007 * * * \\
(0.002)\end{array}$ & $\begin{array}{c}-0.005 * * * \\
(0.001)\end{array}$ \\
\hline same law & $\begin{array}{c}0.042 * * * \\
(0.011)\end{array}$ & $\begin{array}{c}0.023^{* *} \\
(0.013)\end{array}$ & $\begin{array}{c}0.063^{* * *} \\
(0.019)\end{array}$ & $\begin{array}{c}0.032 * * \\
(0.014)\end{array}$ & $\begin{array}{c}0.049 * * * \\
(0.015)\end{array}$ \\
\hline legal distance & $\begin{array}{c}-0.015^{* * * *} \\
(0.005)\end{array}$ & $\begin{array}{c}-0.019 * * * \\
(0.007)\end{array}$ & $\begin{array}{l}-0.009 \\
(0.006)\end{array}$ & $\begin{array}{c}-0.019 * * * \\
(0.006)\end{array}$ & $\begin{array}{l}-0.009 \\
(0.006)\end{array}$ \\
\hline cultural distance & $\begin{array}{c}-0.006^{*} \\
(0.003)\end{array}$ & $\begin{array}{c}-0.008^{* *} \\
(0.003)\end{array}$ & $\begin{array}{l}-0.004 \\
(0.007)\end{array}$ & $\begin{array}{l}-0.004 \\
(0.003)\end{array}$ & $\begin{array}{c}-0.009 * * \\
(0.004)\end{array}$ \\
\hline log experience & $\begin{array}{c}0.047 * * * \\
(0.008)\end{array}$ & $\begin{array}{c}0.032 * * * \\
(0.008)\end{array}$ & $\begin{array}{c}0.080 * * * \\
(0.012)\end{array}$ & $\begin{array}{c}0.046^{* * *} \\
(0.008)\end{array}$ & $\begin{array}{c}0.043^{* * *} \\
(0.008)\end{array}$ \\
\hline newcomer & $\begin{array}{c}-0.281 * * * \\
(0.045)\end{array}$ & $\begin{array}{c}-0.261^{* * *} \\
(0.050)\end{array}$ & $\begin{array}{c}-0.324 * * * \\
(0.046)\end{array}$ & $\begin{array}{c}-0.271 * * * \\
(0.052)\end{array}$ & $\begin{array}{c}-0.265^{* * *} \\
(0.043)\end{array}$ \\
\hline old hand & $\begin{array}{c}-0.044 * * * \\
(0.007)\end{array}$ & $\begin{array}{c}-0.033^{* * *} \\
(0.008)\end{array}$ & $\begin{array}{c}-0.058 * * * \\
(0.010)\end{array}$ & $\begin{array}{c}-0.038 * * * \\
(0.007)\end{array}$ & $\begin{array}{c}-0.043 * * * \\
(0.010)\end{array}$ \\
\hline repeated & $\begin{array}{c}0.432 * * * \\
(0.029)\end{array}$ & $\begin{array}{c}0.378 * * * \\
(0.062)\end{array}$ & $\begin{array}{c}0.496^{* * * *} \\
(0.019)\end{array}$ & $\begin{array}{c}0.375 * * * \\
(0.040) \\
\end{array}$ & $\begin{array}{c}0.477 * * * \\
(0.041) \\
\end{array}$ \\
\hline $\begin{array}{l}\text { Panel C: local VC is experienced } \\
\text { log distance, distXexpLocal }\end{array}$ & $\begin{array}{c}0.000 \\
(0.002)\end{array}$ & $\begin{array}{l}-0.002 \\
(0.001)\end{array}$ & $\begin{array}{c}0.002 \\
(0.003)\end{array}$ & $\begin{array}{l}-0.003 \\
(0.002)\end{array}$ & $\begin{array}{c}0.005 \\
(0.004)\end{array}$ \\
\hline same law & $\begin{array}{c}0.066^{* * *} \\
(0.017)\end{array}$ & $\begin{array}{c}0.044 * * \\
(0.020)\end{array}$ & $\begin{array}{c}0.089 * * * \\
(0.029)\end{array}$ & $\begin{array}{c}0.048 * * \\
(0.022)\end{array}$ & $\begin{array}{c}0.087 * * * \\
(0.022)\end{array}$ \\
\hline legal distance & $\begin{array}{c}-0.023 * * * \\
(0.007)\end{array}$ & $\begin{array}{c}-0.028 * * * \\
(0.010)\end{array}$ & $\begin{array}{l}-0.013 \\
(0.008)\end{array}$ & $\begin{array}{c}-0.028 * * * \\
(0.008)\end{array}$ & $\begin{array}{l}-0.016 \\
(0.010)\end{array}$ \\
\hline cultural distance & $\begin{array}{l}-0.009 * \\
(0.005)\end{array}$ & $\begin{array}{l}-0.011^{* *} \\
(0.005)\end{array}$ & $\begin{array}{l}-0.005 \\
(0.010)\end{array}$ & $\begin{array}{l}-0.007 \\
(0.005)\end{array}$ & $\begin{array}{c}-0.017^{* *} \\
(0.008)\end{array}$ \\
\hline log experience & $\begin{array}{c}0.075^{* * *} \\
(0.009)\end{array}$ & $\begin{array}{l}0.048 * * * \\
(0.011)\end{array}$ & $\begin{array}{l}0.113^{* * * *} \\
(0.011)\end{array}$ & $\begin{array}{l}0.069 * * * \\
(0.008)\end{array}$ & $\begin{array}{c}0.076 * * * \\
(0.014)\end{array}$ \\
\hline newcomer & $\begin{array}{c}-0.394 * * * \\
(0.044)\end{array}$ & $\begin{array}{c}-0.348 * * * \\
(0.056)\end{array}$ & $\begin{array}{c}-0.418 * * * \\
(0.037)\end{array}$ & $\begin{array}{c}-0.366 * * * \\
(0.048)\end{array}$ & $\begin{array}{c}-0.405^{* * *} \\
(0.049)\end{array}$ \\
\hline old hand & $\begin{array}{c}-0.071 * * * \\
(0.009)\end{array}$ & $\begin{array}{c}-0.050 * * * \\
(0.011)\end{array}$ & $\begin{array}{c}-0.084 * * * \\
(0.015)\end{array}$ & $\begin{array}{c}-0.059 * * * \\
(0.010)\end{array}$ & $\begin{array}{c}-0.079 * * * \\
(0.015)\end{array}$ \\
\hline repeated & $\begin{array}{c}0.518^{* * *} \\
(0.017)\end{array}$ & $\begin{array}{l}0.461^{* * *} \\
(0.060)\end{array}$ & $\begin{array}{l}0.532 * * * \\
(0.014)\end{array}$ & $\begin{array}{l}0.457 * * * \\
(0.029)\end{array}$ & $\begin{array}{c}0.572 * * * \\
(0.022)\end{array}$ \\
\hline VC country dummies & yes & yes & yes & yes & yes \\
\hline Deal fixed effects & yes & yes & yes & yes & yes \\
\hline Pseudo $R^{2}$ & 0.273 & 0.292 & 0.260 & 0.280 & 0.267 \\
\hline Number of obs. (deal-VC pairs) & $7,647,729$ & $3,544,850$ & $3,544,850$ & $4,391,041$ & $2,771,844$ \\
\hline Number of deals & 3,314 & 1,533 & 1,534 & 1,900 & 1,200 \\
\hline
\end{tabular}

${ }^{*} \mathrm{p}<0.10,{ }^{* *} \mathrm{p}<0.05,{ }^{* * *} \mathrm{p}<0.01$ (standard errors clustered at PC country and year (see Petersen 2009) in parentheses). 


\begin{tabular}{|c|c|c|c|c|}
\hline & $\begin{array}{c}\text { Model } 1 \\
\text { All cross- } \\
\text { border deals } \\
\text { CB }\end{array}$ & $\begin{array}{c}\text { Model } 2 \\
\text { Stand-alone cross- } \\
\text { border deals } \\
\text { CBA }\end{array}$ & $\begin{array}{c}\text { Model 3 } \\
\text { Foreign-local } \\
\text { syndicated deals } \\
\text { CBLO }\end{array}$ & $\begin{array}{c}\text { Chow test } \\
\text { Model } 2 \text { vs. } \\
\text { Model } 3\end{array}$ \\
\hline $\log$ distance $_{\mathrm{PC}, \mathrm{VC}}$ & $\begin{array}{c}-0.383^{* * *} \\
(0.063)\end{array}$ & $\begin{array}{c}-0.344 * * * \\
(0.040)\end{array}$ & $\begin{array}{c}-0.095^{* * *} \\
(0.012)\end{array}$ & $13.19 * * *$ \\
\hline same law ${ }_{P C, V C}$ & $\begin{array}{c}0.558 * * * \\
(0.093)\end{array}$ & $\begin{array}{c}0.351^{* * *} \\
(0.088)\end{array}$ & $\begin{array}{c}0.147 * * * \\
(0.027)\end{array}$ & $4.88 * *$ \\
\hline legal distance $\mathrm{PC}, \mathrm{VC}$ & $\begin{array}{c}-0.053 * * \\
(0.022)\end{array}$ & $\begin{array}{c}-0.047^{* *} \\
(0.019)\end{array}$ & $\begin{array}{c}-0.018 * * * \\
(0.005)\end{array}$ & 1.34 \\
\hline cultural distance $_{\mathrm{PC}, \mathrm{VC}}$ & $\begin{array}{l}-0.004 * \\
(0.002)\end{array}$ & $\begin{array}{c}-0.009 * * * \\
(0.002)\end{array}$ & $\begin{array}{c}-0.002 * * * \\
(0.001)\end{array}$ & $6.34 * *$ \\
\hline growth $_{\mathrm{PC}, \mathrm{t}}$ & $\begin{array}{c}0.076 \\
(0.046)\end{array}$ & $\begin{array}{c}0.044 \\
(0.051)\end{array}$ & $\begin{array}{c}0.018 \\
(0.013)\end{array}$ & 0.18 \\
\hline GDPcapPC,t-1 $_{1}$ & $\begin{array}{c}-0.005 \\
(0.154)\end{array}$ & $\begin{array}{c}0.024 \\
(0.119)\end{array}$ & $\begin{array}{c}-0.043 \\
(0.032)\end{array}$ & 0.46 \\
\hline innov $_{\mathrm{PC}, \mathrm{t}-1}$ & $\begin{array}{c}0.974 * * * \\
(0.244)\end{array}$ & $\begin{array}{c}0.676 * * * \\
(0.220)\end{array}$ & $\begin{array}{c}0.177 * * * \\
(0.060)\end{array}$ & $4.56^{* *}$ \\
\hline VCindex $_{\mathrm{PC}, \mathrm{t}-1}$ & $\begin{array}{c}-0.086 \\
(0.065)\end{array}$ & $\begin{array}{l}-0.010 \\
(0.064)\end{array}$ & $\begin{array}{l}-0.016 \\
(0.016)\end{array}$ & 0.05 \\
\hline marketcapPC,t-1 & $\begin{array}{c}0.080 \\
(0.130)\end{array}$ & $\begin{array}{c}0.092 \\
(0.130)\end{array}$ & $\begin{array}{c}0.031 \\
(0.036)\end{array}$ & 0.17 \\
\hline VCsize $_{\text {PC,t-1 }}$ & $\begin{array}{l}0.069 * \\
(0.039)\end{array}$ & $\begin{array}{c}0.038 \\
(0.051)\end{array}$ & $\begin{array}{c}0.006 \\
(0.012)\end{array}$ & 0.48 \\
\hline growth $_{\mathrm{VC}, \mathrm{t}}$ & $\begin{array}{c}-0.053 \\
(0.046)\end{array}$ & $\begin{array}{c}-0.078 * * \\
(0.036)\end{array}$ & $\begin{array}{c}-0.065^{* * *} \\
(0.011)\end{array}$ & 0.08 \\
\hline $\mathrm{GDPcap}_{\mathrm{VC}, \mathrm{t}-1}$ & $\begin{array}{c}0.592 * * * \\
(0.141)\end{array}$ & $\begin{array}{c}0.246 * * * \\
(0.078)\end{array}$ & $\begin{array}{c}0.008 \\
(0.020)\end{array}$ & $6.83 * * *$ \\
\hline innov $_{\mathrm{VC}, \mathrm{t}-1}$ & $\begin{array}{c}0.678 * * * \\
(0.188)\end{array}$ & $\begin{array}{c}0.161 * * * \\
(0.052)\end{array}$ & $\begin{array}{c}0.059 * * * \\
(0.013)\end{array}$ & $2.73^{*}$ \\
\hline VCindex $_{\mathrm{VC}, \mathrm{t}-1}$ & $\begin{array}{c}0.041 \\
(0.053)\end{array}$ & $\begin{array}{c}0.128 * * * \\
(0.036)\end{array}$ & $\begin{array}{c}0.043 * * * \\
(0.009)\end{array}$ & $3.67 *$ \\
\hline marketcap $_{\mathrm{vc}, \mathrm{t}-1}$ & $\begin{array}{c}0.316^{* * *} \\
(0.110)\end{array}$ & $\begin{array}{c}0.169 * * * \\
(0.040)\end{array}$ & $\begin{array}{c}0.052 * * * \\
(0.011)\end{array}$ & $6.23 * *$ \\
\hline VCsize $_{\text {VC,t-1 }}$ & $\begin{array}{l}-0.038 \\
(0.040)\end{array}$ & $\begin{array}{c}-0.065^{* *} \\
(0.031)\end{array}$ & $\begin{array}{l}-0.012 \\
(0.008)\end{array}$ & $3.22 *$ \\
\hline VC country dummies & yes & yes & yes & \\
\hline $\begin{array}{l}\text { PC country dummies } \\
\text { year dummies }\end{array}$ & $\begin{array}{l}\text { yes } \\
\text { yes }\end{array}$ & $\begin{array}{l}\text { yes } \\
\text { yes }\end{array}$ & $\begin{array}{l}\text { yes } \\
\text { yes }\end{array}$ & \\
\hline$x^{2}$ & 248.4 & 1652.1 & 2407.6 & \\
\hline Number of obs. (country-pair-years) & 6,496 & 6,496 & 6,496 & \\
\hline Number of countries & 29 & 29 & 29 & \\
\hline Number of years & 8 & 8 & 8 & \\
\hline
\end{tabular}

${ }^{*} \mathrm{p}<0.10,{ }^{* *} \mathrm{p}<0.05,{ }^{* * *} \mathrm{p}<0.01$ (standard errors in parentheses). 


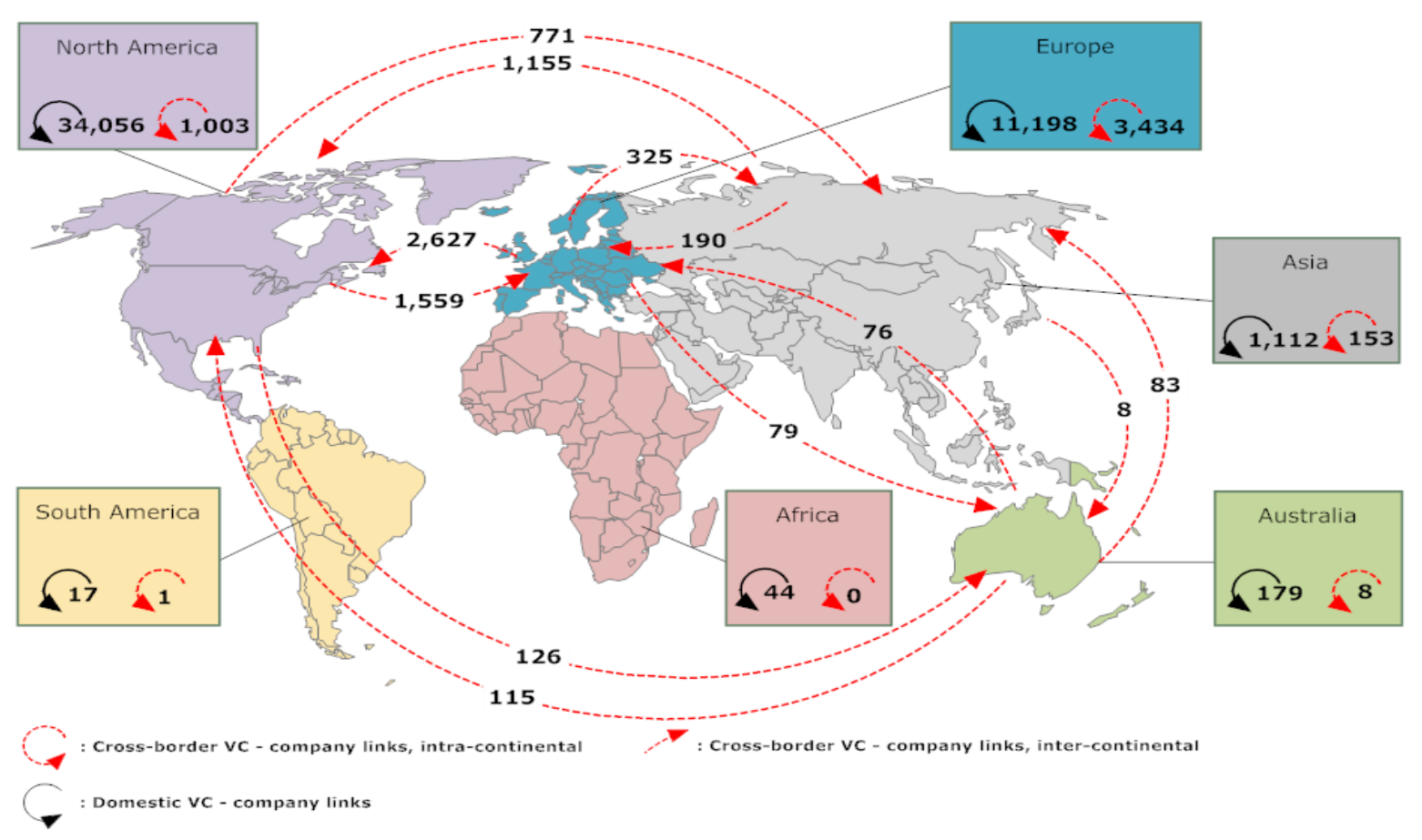

Figure 1 Local, intracontinental and intercontinental cross-border VC-PC links

Source: Authors' calculation from Zephyr data (2000-2008). 


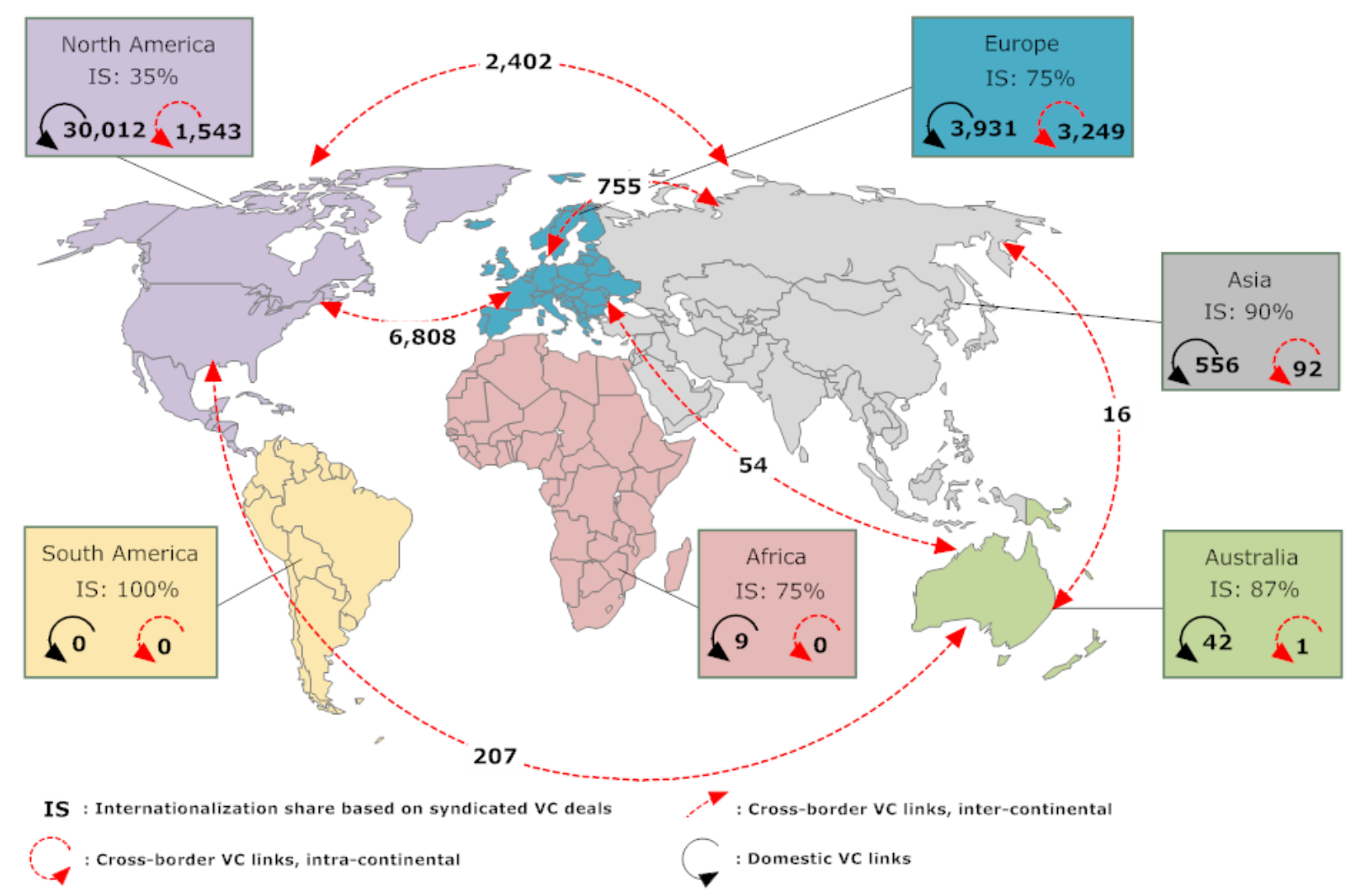

Figure 2 Local, intracontinental and intercontinental cross-border links between VCs Source: Authors' calculation from Zephyr data (2000-2008). 


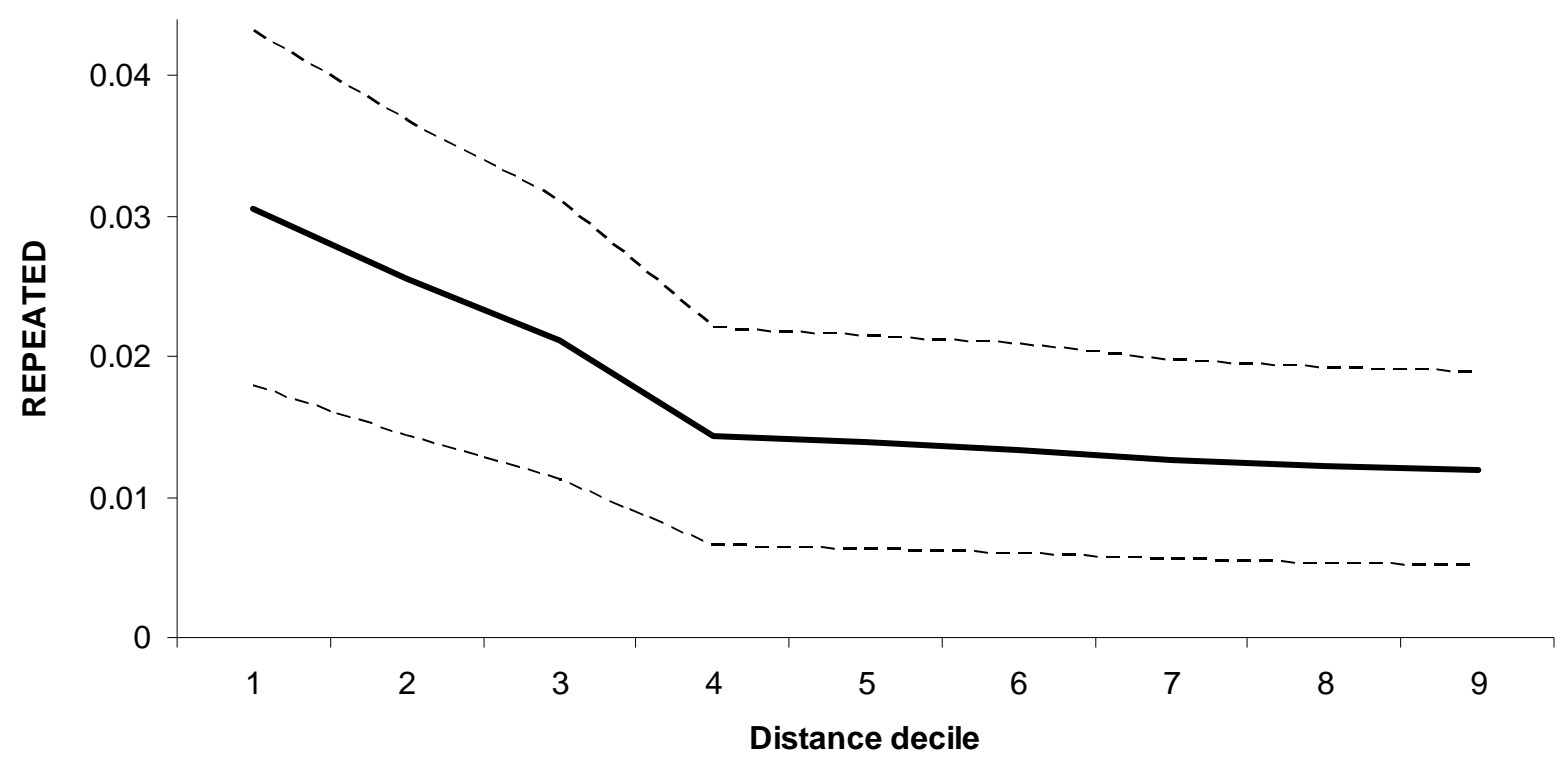

Figure 3 Marginal effects of repeated relationship to a local VC at distance deciles Source: Authors' calculation based on the model 1 from Table 4 . 

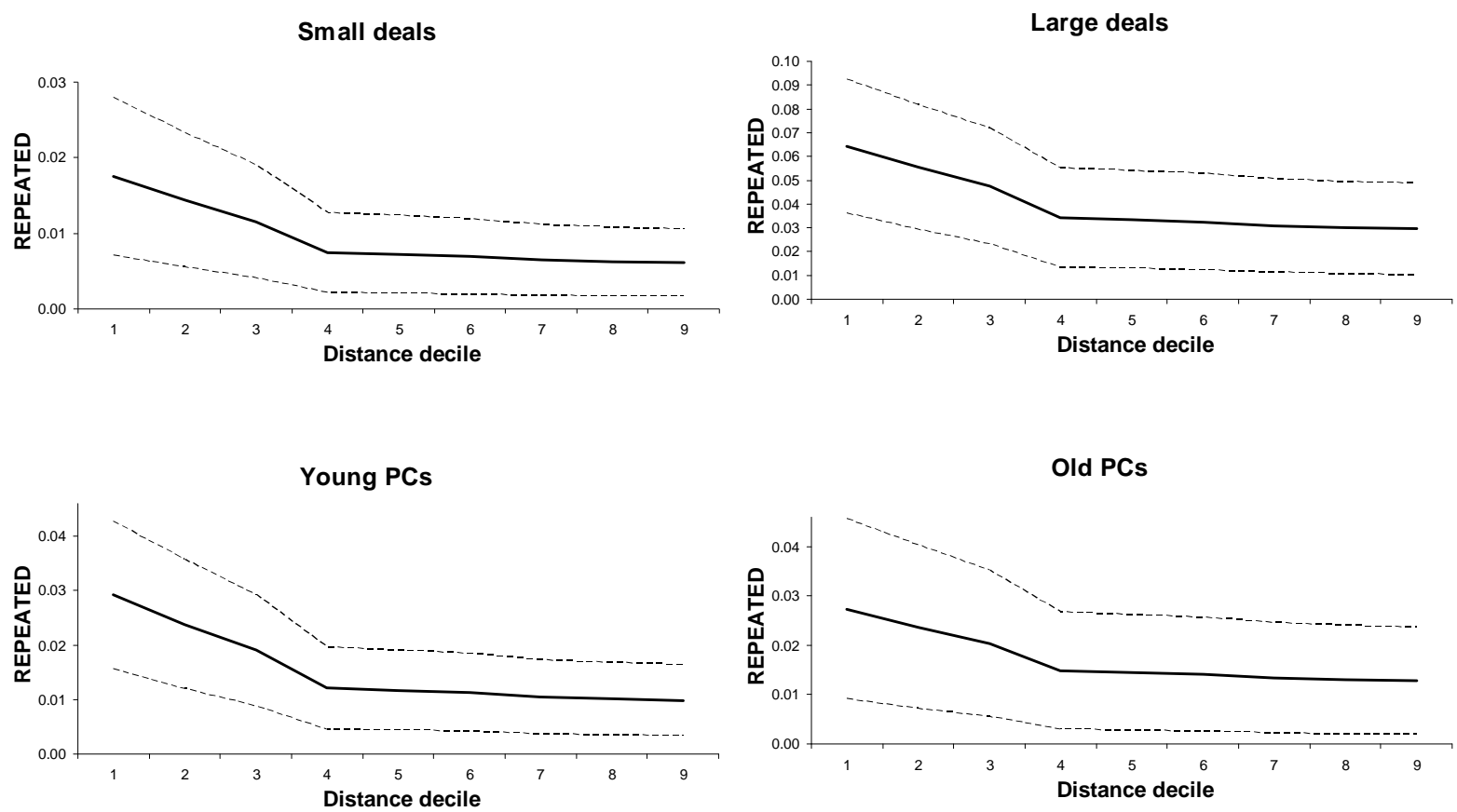

Figure 4 Marginal effects of repeated relationship to a local VC at distance deciles for different subsamples

Source: Authors' calculation based on the models 2-5 from Table 4. 


\section{Appendix 1: Information about the Zephyr database}

We use data on worldwide venture capital deals from Bureau van Dijk’s Zephyr database, which offers information on mergers and acquisitions, initial public offerings, as well as private equity and venture capital deals. Researchers working in the field of venture capital and private equity (e.g., Goossens et al. 2008, Abdesselam et al. 2008, Bloom et al. 2009, Brav et al. 2009, Beuselinck et al. 2009, Prijcker et al. 2009) have become aware of the existence of this database in recent years. For the purposes of this paper, we collected information on worldwide venture capital deals in the period 2000-2008, in particular on the geographical locations of the venture capitalists (VCs) and their portfolio companies (country of origin, city, zip code). We have identified venture capital deals from the Zephyr database using multiple criteria. In the first step, we searched the database for deals financed by one of the following: venture capital, private equity, angel investment, corporate venturing, or seed financing. In the second step, we considered only minority deals from this dataset. In the third step, we analyzed the business description of the investors and only retained investors whose business description included "venture capital.” Fourth, we kept only non-financial companies as target portfolio companies in our sample. Fifth, we excluded corporations and governments as VCs.

The nature of this dataset has raised the need for intensive reorganization. We will describe the main steps in the next few paragraphs.

We filled in missing deal (VC) information from other deals whenever the deal (VC) identification number was identical. Moreover, we split deals with multiple portfolio companies into separate observations and deleted all deals with missing investor names and countries and/or company and country names, as well as deals recorded for "wealthy individuals”, “institutional investors” or other non-identifiable investors (without an identification number). We also excluded all deals in which the portfolio company and its investor were identical and in which no third party was involved. We started with 38,125 total (i.e., local and cross-border) venture capital deals. After applying the criteria described above, the number of deals in our final dataset dropped to 23,826.

The next step required more sophistication, as we moved closer to the core of the organizational structure of the VCs. In some cases, the identity of the VC in Zephyr was indicated at the level of the venture capital fund, in other cases at the level of the venture capital company. In addition, the parent company was sometimes specified as investor, whereas in other cases it was the subsidiary. To achieve a consistent pattern, we collected data at the "highest" level, using the information on ultimate parent companies offered by Zephyr. In order to be classified as a venture capitalist for our analysis, either the subsidiary or the parent company had to be a venture capitalist. However, an important characteristic of the dataset was that parent company information in Zephyr had been updated regularly, so that - relying only on the information indicated in the field "parent company" - we were not able to trace back changes in the organizational structure. What is the drawback of this feature? Let investor A take over a share in target $Z$ on January 1st 2004. If a different enterprise B took over investor A on January 1st 2003, we would attribute the above-mentioned deal to B, because B became 
A's parent before the deal was conducted. However, if B took over A on January 1st 2005, the aboveindicated deal was carried out by A, because at the date of the deal, A and B were independent. However - using the parent information offered by Zephyr - we would have falsely assigned this deal to B since B was indicated as A's parent. To correct this “mistake”, we checked whether our investors (within the Zephyr database) had been acquired or merged during the period under observation. All deals before a potential acquisition or merger date (in the latter example: January 1st 2005) were then assigned to the original investor, all deals after this date to its parent company.

To sum up, all venture capital funds and subsidiaries were aggregated to their parent company and inherited the characteristics of the parent company (i.e., geographic location, repeated relationships, number of deals). Acquired venture capital firms were aggregated to their acquirers at the effective date of the merger. In addition, acquiring venture capital firms inherited the accumulated VC deals and the previous relationships of the acquired firm.

Given the lack of systematic research into venture capital financing outside the U.S., we are limited in our ability to calibrate the completeness of the Zephyr database. Nonetheless, we can assess its completeness by comparing it with the data in other studies and in other databases. In the Zephyr database, we count 38,125 local and cross-border venture capital deals in 26,180 companies in the period 2000-2008. The most recent paper by Lerner et al. (2009) is based on the Capital IQ database and includes 45,207 venture capital and growth capital deals worldwide from 1984 through September 2008. Unfortunately, the paper does not provide information on the number of deals within the period 2000-2008, so that it is not directly comparable to our sample. The most widely used database in venture capital research, the Thomson VentureXpert database, has been used in a comparable period by Brander et al. (2010). They find 20,556 companies worldwide that received their first venture capital funding between 2000 and 2008. Thus, Zephyr does not have worse coverage than both these databases. 


\title{
Appendix 2: Data description and sources
}

\section{$\underline{\text { A - Individual deal level }}$}

Dependent variable (based on Zephyr data)

$\mathrm{p}_{\mathrm{IJ}} \quad$ Participation in cross-border deals: takes the value one if venture capitalist $I$ (located outside the country in which the deal takes place) participates in deal $J$, and zero otherwise.

$\mathrm{P}_{\underline{\underline{I}}}$

Participation in syndicated deals: takes the value one if venture capitalist $I$ participates in the syndicated deal $J$, and zero otherwise.

\begin{abstract}
Independent variables
distance $_{\mathrm{IJ}} \quad$ Distance $(+0.01)$ between venture capitalist (VC) $I$ and the deal $J$ in miles.

same law ${ }_{\mathrm{PC}, \mathrm{VC}} \quad$ Dummy variable equal to one if the VC and portfolio company's (PC) countries have the same law tradition based on French, German, English, Scandinavian or Socialist law; zero otherwise (source: La Porta et al. 1998).

legal distance $_{\mathrm{PC}, \mathrm{VC}}$ Difference between the legality index in the VC and the PC country. The legality index is a weighted average of the following factors: efficiency of judicial system, rule of law, corruption, risk of expropriation, risk of contract repudiation, and shareholder rights (source: Berkowitz et al. 2003).

cultural distance $_{\mathrm{PC}, \mathrm{VC}}$ Difference between the Hofstede's power distance index in the VC and the PC country. The power distance index captures the extent to which the less powerful members of organizations and institutions accept and expect that power is distributed unequally (source: http://www.geerthofstede.com/hofstede_dimensions.php).

experience $_{\mathrm{IJ}} \quad$ Number of deals carried out by VC I during a three-year period preceding the investment in deal $J$. local $_{J} \quad$ Dummy variable equal to one if a local VC participates in cross-border deal $J$.

newcomer $_{\mathrm{IJ}} \quad$ Dummy variable equal to one if a foreign VC $I$ has not invested in the country in which deal $J$ takes place during the previous three years.

old hand $\mathrm{IJ}_{\mathrm{IJ}} \quad$ Dummy variable equal to one if a foreign VC $I$ has already invested in the country in which deal $J$ takes place.

repeated $_{\mathrm{IJ}} \quad$ Dummy variable equal to one if VC $I$ invested together with one of the local VC participating in deal $J$ (participation in cross-border deals) or with the closest local VC participating in deal $J$ (participation in syndicated deals) during the previous three years, zero otherwise.
\end{abstract}

\section{$\underline{\text { B - Bilateral-country level }}$}

Dependent variables (based on Zephyr data)

$\mathrm{CB}_{\mathrm{PC}, \mathrm{VC}, \mathrm{t}} \quad$ Volume of bilateral cross-border links from the VC country to the PC country in year $t$ calculated from individual deal data, normalized by the logarithm of the GDP product of both countries. If deals are syndicated among several VCs from different countries, the deal volume is divided equally among these VCs, since we only have information on the total deal volume.

$\mathrm{CBA}_{\mathrm{PC}, \mathrm{VC}, \mathrm{t}} \quad$ Subvolume of $\mathrm{CB}_{\mathrm{PC}, \mathrm{VC}, \mathrm{t}}$ including only stand-alone deals.

$\mathrm{CBLO}_{\mathrm{PC}, \mathrm{VC}, \mathrm{t}} \quad$ Subvolume of $\mathrm{CB}_{\mathrm{PC}, \mathrm{VC}, \mathrm{t}}$ including only those deals that are syndicated between foreign and local VCs.

Independent variables

distance $_{\mathrm{PC}, \mathrm{VC}} \quad$ Distance between the main city of the PC country and the VC country in miles. In most cases (except Australia, Brazil, Canada, Germany, and the United States), the main city is the capital of the country (source: www.cepii.fr).

same law ${ }_{\mathrm{PC}, \mathrm{VC}}$ see individual deal level

legal distance $\mathrm{PC}_{\mathrm{PC}}$ see individual deal level

cultural distance $\mathrm{PC}_{\mathrm{PC}}$ see individual deal level

VCsize $_{\mathrm{yt}}$ Number of local VCs with at least one local deal in country $y$ (= PC or VC country) and year $t$ (source: Zephyr) normalized by GDP in year $t$.

growth $_{\mathrm{yt}}$ Expected real GDP growth rate (in percent) for the next 3-5 years in country $y$ (= PC or VC country) and year $t$ (source: Datastream).

$\operatorname{innov}_{\mathrm{yt}}$ Business R\&D expenditures normalized by GDP in country $y$ (= PC or VC country) and year $t$ (source: IMD World Competitiveness Yearbook).

GDPcap $_{y t}$ GDP per capita in th. USD at purchasing power parity in country y (= PC or VC country) and year $t$, (source: IMD World Competitiveness Yearbook).

VCindex $_{\mathrm{yt}}$ Venture capital index (higher value is better) in country y (= PC or VC country) and year $t$ (source: IMD World Competitiveness Yearbook).

marketcap $_{\mathrm{yt}}$ Stock market capitalization normalized by GDP in country $y$ (= PC or VC country) and year $t$ (source: Worldbank). 
i We need the first three years to generate variables related to VCs' general and within-country experience and repeated relationships.

ii However, the results are robust towards other specifications, e.g., choosing the "local” VC randomly.

iii We have used alternative interaction terms, such as an interaction between the dummy variable for a local VC and the general experience of the foreign VC. These alternative interaction terms do not change our main results.

iv Vincenty (1975) developed a formula for calculating geodesic distances between a pair of points on the surface of the Earth using an accurate ellipsoidal model of the Earth.

v E.g., Meuleman et al. (2009) and Meuleman and Wright (2011) use a five-year window to obtain information on repeated relationships. However, given the short time period our data covers, we opt for this shorter window.

vi In the regression, we use $\log ($ distance $)$. Doubling the mean distance results in $\log (2 \times$ meandistance $)=\log (2)+\log$ (meandistance). Extracting the mean distance from this expression gives $\log (2)=0.69$, which is the change in the transformed distance variable (i.e., $\log (2 \times$ meandistance)- $\log ($ meandistance $)$ ). The marginal effect amounts to -0.003 . Thus, if the distance doubles, the probability change equals approximately: $-0.003 * 0.69=0.0021$.

vii We use deals from the year 2000 to create an independent variable.

viii We were able to collect all independent variables for these 29 sample countries.

ix The high significance levels on the geographical distance marginal effects might raise concerns. However, fairly high values are hardly an uncommon occurrence in literature on other types of international cross-border flows. For example, in their basis table, Portes and Rey (2005) present seven different models with an average t-value on the distance coefficient of minus 20 . 